Florida International University FIU Digital Commons

\title{
Impacts of the Naturalized Bee Centris nitida on a Specialized Native Mutualism in Southern Florida
}

Jason L. Downing

Florida International University, jdown003@fiu.edu

DOI: $10.25148 /$ etd.FI1 1050604

Follow this and additional works at: https://digitalcommons.fiu.edu/etd

\section{Recommended Citation}

Downing, Jason L., "Impacts of the Naturalized Bee Centris nitida on a Specialized Native Mutualism in Southern Florida" (2011). FIU Electronic Theses and Dissertations. 389.

https://digitalcommons.fiu.edu/etd/389 


\section{FLORIDA INTERNATIONAL UNIVERSITY \\ Miami, Florida}

\section{IMPACTS OF THE NATURALIZED BEE CENTRIS NITIDA ON A SPECIALIZED NATIVE MUTUALISM IN SOUTHERN FLORIDA}

A thesis submitted in partial fulfillment of the

requirements for the degree of

MASTER OF SCIENCE

in

ENVIRONMENTAL STUDIES

by

Jason Lamar Downing 
To: Dean Kenneth G. Furton

College of Arts and Sciences

This thesis, written by Jason Lamar Downing, and entitled Impacts of the Naturalized Bee Centris nitida on a Specialized Native Mutualism in Southern Florida, having been approved in respect to style and intellectual content, is referred to you for judgment.

We have read this thesis and recommend that it be approved.

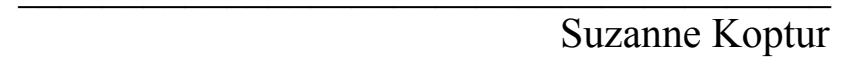

Krishnaswamy Jayachandran

Hong Liu, Major Professor

Date of Defense: March 30, 2011

The thesis of Jason Lamar Downing is approved.

Dean Kenneth G. Furton

College of Arts and Sciences

Interim Dean Kevin O'Shea

University Graduate School

Florida International University, 2011 


\section{DEDICATION}

I dedicate this thesis to wife and son, my parents, and my family without their support this journey would not be possible. 


\section{ACKNOWLEDGMENTS}

I would like to thank my major advisor Dr. Hong Liu for her mentorship and providing me with the opportunity to participate in ecological research. I also wish to thank the members of my committee, Dr. Suzanne Koptur and Dr. Krishnaswamy Jayachandran (Dr. Jay) for their continued support and advice. Special thanks to David Herbella and Daniel Alfonso for their help with the fieldwork. Last, to all of the friends and staff at Fairchild Tropical Botanic Garden, Montgomery Botanical Center, and the Center for Tropical Plant Conservation thank you for access to the amazing collections and support during my graduate studies. 


\begin{abstract}
OF THE THESIS
IMPACTS OF THE NATURALIZED BEE CENTRIS NITIDA ON A SPECIALIZED NATIVE MUTUALISM IN SOUTHERN FLORIDA
\end{abstract}

by

Jason Lamar Downing

Florida International University, 2011

Miami, Florida

Professor Hong Liu, Major Professor

This study assesses the impacts of the invasive oil-collecting bee Centris nitida on the established endemic mutualism between Byrsonima lucida and Centris errans its sole native pollinator. In natural pine rocklands and urban areas, I examined the breeding system of B. lucida, assessed the degree of its pollen limitations, and compared the key processes of pollination for the Centris bees. Breeding system results showed that $B$. lucida was self incompatible and pollinator dependent. Pollen limitation treatments suggested that B. lucida is pollen limited, regardless of the contributions of the invasive bee. The native bee had significantly higher visitation rates to B. lucida plants, but had a lower foraging rate and was the less efficient pollinator. The invasive bee appears to be more common in urban environments. Further understanding the nature of these novel relationships is vital for the conservation of $B$. lucida and integrity of pine rocklands. 


\section{TABLE OF CONTENTS}

CHAPTER

PAGE

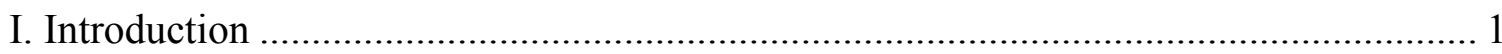

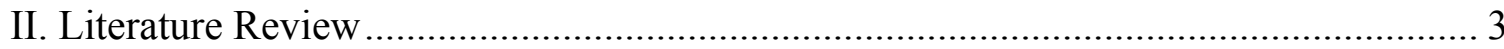

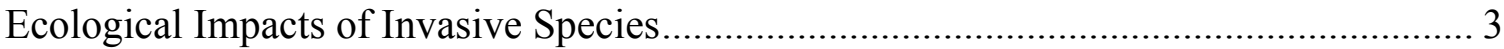

Community and Population Level Impacts................................................................ 4

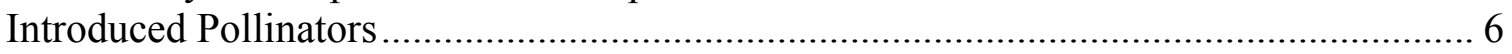

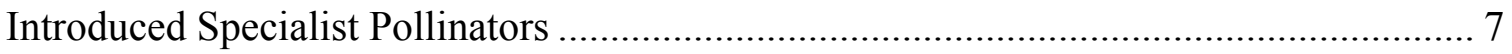

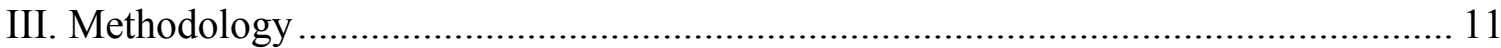

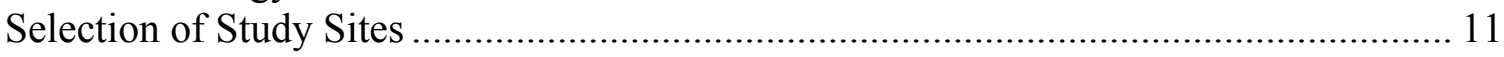

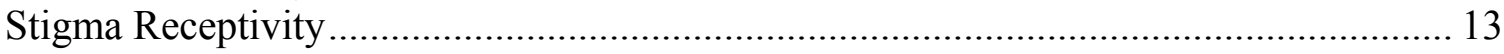

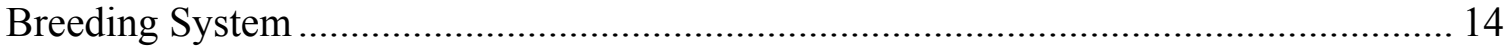

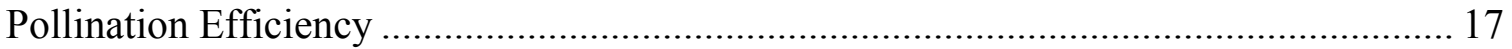

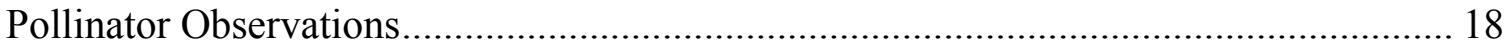

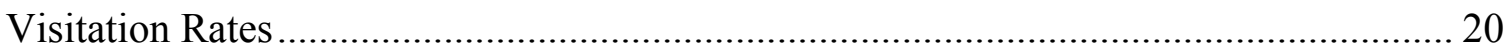

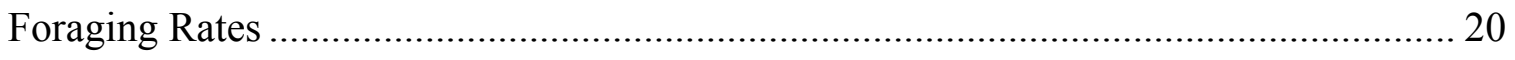

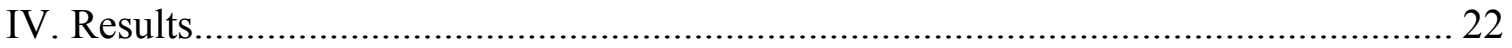

Breeding System and Pollinator Efficiency ............................................................... 22

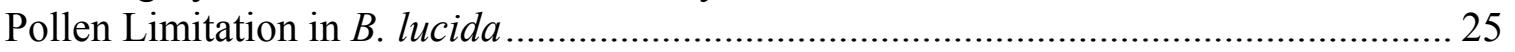

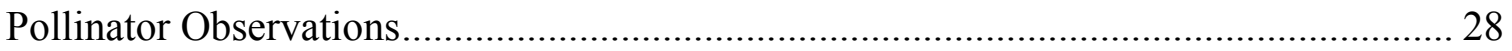

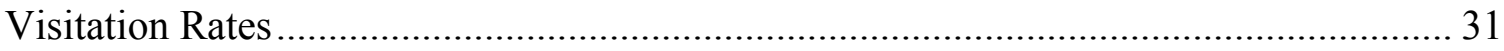

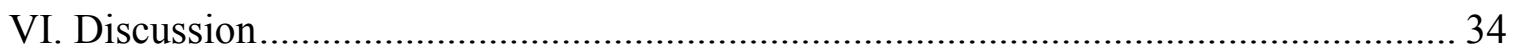

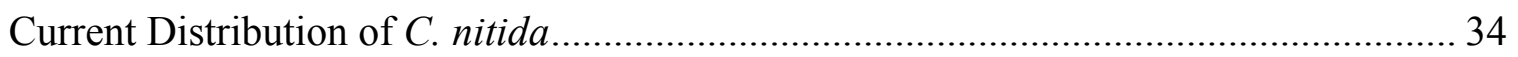

Behavioral differences between Centris bees and other floral visitors............................. 36

Promotion of fruit set in B. lucida by native versus invasive oil bees............................. 38

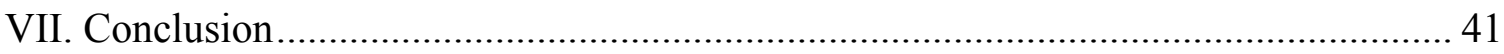

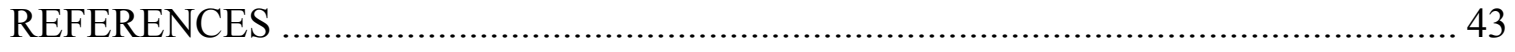

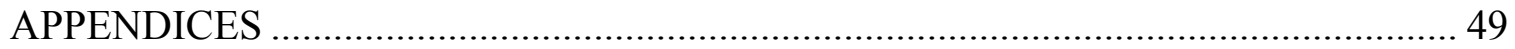




\section{LIST OF TABLES}

TABLE

PAGE

1. Logistic regression tables showing mean differences in receptivity scores

2. One-Way ANOVA table showing effects of all seven pollination treatments on percentage of fruit sets of Byrsonima lucida in Garden site 1 (Fairchild Garden). 25

3. Two-way ANOVA table showing the interactions between two pollination treatments (control and pollen supplement) and garden versus natural sites on mean fruit set. ........ 26

4. Two-way ANOVA showing interactions between two pollination treatments (control and pollen supplement) and sites with and without the introduced bee on mean fruit set.

5. One- Way ANOVA table showing the variance in mean visitation rates among three floral visitors to Byrsonima lucida.

6. One-way ANOVA table showing the variance in mean foraging rates among three floral visitors to Byrsonima lucida. 33 


\section{TABLE OF FIGURES}

FIGURE

PAGE

1. Map showing residential garden and natural pine rockland study sites in Miami-Dade County, Florida. 12

2. Bar graph showing the percentage of flowers that scored positive for stigma receptivity for three color phases of Bysonima lucida flowers. $\mathrm{N}=$ number of flowers and each flower represents a replicate.

3. Comparison of the mean fruit set by Byrsonima lucida for all pollination treatments at garden site 1 (Fairchild Garden). The treatments "Centris errans" and "Centris nitida" were single visits by only one bee to the flower. At this site Centris errans was the dominant floral visitor. $\mathrm{N}=$ indicates the number of replicates for each treatment (each replicate consists of at least 10 flowers) and error bars represent standard error (SE) of each treatment.

4. Bar graph comparing mean fruit set for control and artificial pollen supplement treatments for at least three plants of Byrsonima lucida at one garden site and five natural pine rockland sites in extreme southern Florida. $\mathrm{N}=$ number replicates for each treatment (each replicate consists of at least 10 flowers) and error bars represent the standard

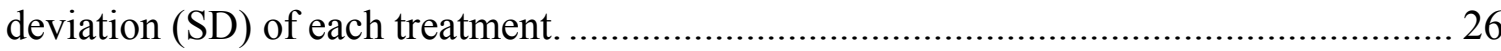

5. Comparison showing there are no differences in the reduction of the percentage fruit set of Byrsonima lucida between the control and pollen supplementation treatments in natural sites with and without the invasive oil bee Centris nitida.

6. Pie chart showing the amount of time watched and the proportion of time occupied by each floral visitor to Byrsonima lucida among all study sites pooled (a), garden sites (b $\& \mathrm{c})$, and natural pine rockland sites (d-h) in extreme southern Florida.

7. Comparison of mean visitation rates of three floral visitors to

8. Comparison of mean foraging rates of three floral visitors to Byrsonima lucida among all study sites pooled. Error bars represent standard error (SE) of each treatment. 


\section{Introduction}

Invasive species are a major threat to natural and agricultural ecosystems. The study of the impacts of invasive species is a rapidly expanding and evolving field with many of its studies centered on high profile environmental crises, such as Africanizedhoney bees, subtropical termites in the southern United States, and Australian melaleuca in the Florida Everglades. As seen in these examples, introduced species can quickly become environmental and economic burdens. The environmental damage and losses caused by non-indigenous species in the United States total more than $\$ 120$ billion annually (Pimentel et al. 2005). Nowhere is this financial burden more evident than in Florida, where the annual cost of invasive plants, animals, and diseases to Florida's agriculture alone is estimated at $\$ 179$ million annually (Adams 2007). As these invasive species spread across Florida, their impacts on endangered and threatened habitats and on the native species therein, increase significantly.

Research examining the ecological impacts of introduced pollinators, mostly generalist bee species (Hymenoptera: Apidae), have increased in intensity in the last decade (Butz Huryn 1997, Goulson 2003) alongside ongoing concerns regarding global declines in bee populations (Kearns et al. 1998). Recently, introduced specialist bees are being discovered in south Florida. The spread of these introduced pollinators may be altering native pollinator-plant mutualisms, some of which involve rare endemic species. The introduced oil-collecting bee Centris nitida $(C$. nitida) has been reported to be established and creating a novel mutualistic relationship with the threatened endemic plant Byrsonima lucida (B. lucida) (Pemberton \& Liu 2008b). The invasive orchid bee Euglossa viridissima (E. viridissima), another specialist bee, has been shown to pollinate 
invasive weeds (Liu \& Pemberton 2009). Since the ecological impacts of introduced specialized pollinators is still relatively unknown, this study will shed light on this topic by examining the impact of an introduced bee on the pollination of a threatened, native, endemic plant and its native pollinator. 


\section{Literature Review}

\section{Ecological Impacts of Invasive Species}

The ecological impacts of invasive species can be grouped under two broad categories; ecosystem level impacts and community/population level impacts (Mack et al. 2000; Randall 2001). At the ecosystem level invasive species have been found to alter ecological processes in at least these key ways: altering fire regimes (D'Antonio \& Vitousek 1992, Schmitz et al. 1997), altering nutrient cycling (Vitousek \& Walker 1989), and altering the rates of sedimentation and soil erosion (Lacey et al. 1989, Gordon 1998 \& Ortega 2005).

On Christmas Island, the yellow crazy ant (Anoplolepis gracilipes) has caused a rapid and catastrophic shift in community structure of native rainforests, subsequently altering entire ecosystem functions (O’Dowd et al. 2003). The invader extirpated key species of land crabs on the island that act as the dominant consumers on the rainforest floor. By reducing the keystone species abundance, the invasive ants have indirectly increased seedling recruitment, enhanced the species richness of seedlings in the understory, and thereby slowing the rates of litter decomposition in the invaded areas (O’Dowd et al. 2003). Melaleuca quinquenervia, an invasive Australian tree introduced to Florida, has increased the intensity and frequency of fires in portions of the Florida Everglades, of which key native species found in those areas are not fire adapted (Schmitz et al. 1997). Myrica faya, native to the Canary Islands, has invaded the Hawaiian forests and shrub lands and altered nutrient cycles (Vitousek \& Walker 1989). It is able to fix nitrogen at a rate of 90 -fold to that of endemic plants on the island 
allowing it to establish in nitrogen deficient volcanic soils (Vitousek \& Walker 1989). Consequently, the additional nutrients assimilated into the soil from the decomposition of the invasive plants have transformed the typically nutrient deficient soils into soils that are more fertile, and therefore increased the potential for a broad range of invaders (Vitousek \& Walker 1989). Making matters worse, in New Zealand, an introduced Japanese bird Zosterops japonica is attracted to M. faya and is known to disperse the seeds (Vitousek \& Walker 1989). Spotted knapweed (Centaurea maculosa) has invaded grasslands and range lands in the Northwest United States (Lacey et al. 1989 \& Shelly et al. 1998). It outcompetes the native bunch grasses, which possess far more complex root systems and act as soil stabilizers. The simpler roots system of the invasive grass does not slow runoff from rainstorms, and as a result soil erosion has increased where the plant is present (Lacey et al. 1989). In turn this has had a negative impact on local salmon streams by increasing the sediment loads and turbidity of the water (Lacey et al. 1989).

\section{Community and Population Level Impacts}

Community and population level impacts of invasive species include, but are not limited to: competition for resources (Beggs \& Wilson 1991, O’Dowd et al. 2003), predation (Goldschmidt 1996, Savidge 1987), grazing (Groombridge 1992, Booth et al. 1995), hybridization (Rhymer \& Simberloff 1996, Thompson 1991), and disease (Goka et al. 2006). Invasive species may directly or indirectly compete with native species for key resources like nutrients, water, light, and space (Randall 2002). They may also alter established native mutualisms (Kearns et al. 1998). In New Zealand two introduced species of fig wasps have been found to negatively impact both invertebrate and 
vertebrate fauna through direct competition for resources (Beggs \& Wilson 1991). The native Kaka, a forest parrot (Nestor meridionalis), collects the honeydew from several native species of scale insect. Since the arrival of the introduced wasp, more than $95 \%$ of this resource is now being claimed by the invader (Beggs \& Wilson 1991). As a result, this has caused the parrot to abandon the native forests, and has decreased the abundance of other honeydew collecting animals (Beggs \& Wilson 1991). Fig wasps also have negatively affected plant communities in California by aiding in the pollination and subsequent fruiting of long established non-native Ficus species (Donovan 1990).

Invasive species may also impact communities through predation. The introduction of a novel predator can have devastating impacts on native prey, which often are naïve to the new threat. The brown tree snake (Boiga irregularis) introduced to Guam in the late 1940's has virtually eliminated all of the endemic forest birds in Guam (Savidge 1987). More recently the lionfish (Pterois volitans), native to the Indo-Pacific Ocean, has invaded a variety of marine ecosystems along the Atlantic Coast and in the Caribbean (Whitfield et al. 2002). The lionfish is a voracious predator and has reduced Caribbean reef fish numbers (Whitfield et al. 2002).

In addition to the more direct impacts, invasive species may eliminate native species through hybridization with native congeners (Mack et al. 2000). This potential impact is a particular danger with rare native species. Hybridization of the North American Mallard (Anas platyrhyncos) with New Zealand Gray Duck (Anas superciliosa) and Hawaiian Duck (Anas wyvilliana) has threatened the persistence of both distinct species (Rhymer \& Simberloff 1996). Hybridization of non-native and native species can also create new invasive species, as seen when North American 
cordgrass (Spartina alterniflora) was introduced to the Europe and hybridized with British cordgrass (Spartina maritima); over time, the hybrids underwent a doubling of the chromosome number, making a fully fertile and highly invasive new species, Spartina anglica (Thompson 1991).

\section{Introduced Pollinators}

Although little is known of the impacts of introduced pollinators, they have been found to alter plant communities and population structure by mediating different patterns of pollen transfer (Dafni \& Shmida 1996, Butz Huyrn 1997, Goulson 2003, Gross \& Mackay 1998, Kearns et al. 1998), and by reducing the effectiveness of pollination, often by being a morphological mismatch with the native flower (Ramsey 1988 \& Burd 1994). By far the most significant introduced pollinators are honey bees (Apis spp.), which have become important pollinators of agricultural crops throughout the world (Butz Huyrn 1997, Goulson 2003, Olmstead \& Wooten 1987, Roubik 2002). Other important pollinator introductions have included: fig wasps, bumble bees (Bombus spp.), carpenter bees (Xylocopa spp.) and tropical specialist bees (Centris and Euglossa spp.) (Kearns et al. 1998, Pemberton \& Liu 2008a,b, Pemberton \& Liu 2009)

Introduced bee pollinators are known to affect ecological systems by competing with native pollinators for resources, pollinating native and non-native flora, pollinating exotic weeds, or by transmitting parasites (Goulson 2003). Honey bees, and to a lesser extent, bumble bees, can have a positive effects on natural systems, in that they are essential pollinators of agricultural crops (Butz Huyrn 1997, Olmstead \& Wooten 1987, Roubik 2002). But introduced pollinators can also have a negative impact on the native 
pollinators. They can deter them from foraging on the best or richest floral resources, or depress the availability of a floral resource (Hingston \& McQuillan 1999, Paini \& Roberts 2005). Introduced pollinators can also promote invasion by invasive plants (Barthell et al. 2001, Stout et al. 2002). In New Zealand and Tasmania, many species of European weeds have dramatically increased in abundance after the introduction of nonnative honey bees and bumble bees (Butz Huyrn \& Moller 1995, Stout et al. 2002), and in North America the honey bee has increased the seed set of the invasive yellow star thistle, Centaurea solstitialis (Barthell et al. 2001). In Florida, introduced pollinators promoted the spread of a self-incompatible invasive woody vine, Paederia foetida (Liu et al. 2006).

\section{Introduced Specialist Pollinators}

The majority of studies examining the impacts of introduced pollinators has focused on the effects of introduced generalist bees, typically honey bees and bumble bees, which gather the common floral rewards of pollen and nectar in native and nonnative ecosystems. However, there are only a few examples of research that focus on the effects of non-native specialist bees on native ecosystems (Pemberton \& Liu 2008 a, b, c, Liu \& Pemberton 2009). Specialist bees are different from honey bees and bumble bees in that they are usually solitary, and they gather unusual rewards such as floral resin or oils, in addition to pollen and nectar. Such requirements allows them to form narrow but strong mutualistic relationships with plant species that offer such specialized rewards.

Introduced specialist pollinators may form these mutualisms in new habitats that duplicate the function or strategies found in their natural ranges. In some cases, they re- 
unite with introduced plants that originated from the same areas as the pollinator or alternatively, they may forge novel mutualistic relationships that can have profound ecological implications (Richardson et. al 2000). A recently naturalized resin-collecting orchid bee, Euglossa viridissima, has formed both novel and existing (in its native range) specialized pollination relationships with introduced horticultural plants in Florida (Liu \& Pemberton 2009). Naturalization of E. viridissima has increased the invasibility of southern Florida's natural ecosystems by offering pollinator services that did not exist in the area previously, and by promoting the spread of the invasive plant Solanum torvum (Liu \& Pemberton 2009). When invasive species alter fundamental ecosystem properties and facilitate future invasions, substantial threats to the environment are posed (Mack et al. 2000). Recently, another non-native specialist bee, Centris nitida, has naturalized, and is considered invasive, in southern Florida; this species may be impacting native communities. The oil collecting bee, $C$. nitida has been reported to be naturalized in the pine rocklands of southeastern Florida and a potential pollinator of native, ornamental, and invasive plants in the region (Pemberton \& Liu 2008b). This invasive bee is one of only two specialist bees established in southern Florida, along with E. viridissima which has been shown to be highly invasive. In South Florida, $C$. nitida is known to visit as many as 24 non-native plants species, including three orchid species two of which are non-native, one of which (Cyrtopodium polyphyllum) is a know invasive (Pemberton \& Liu 2008b).

The genus Centris (Apidae: Centridini) is an important group of oil collecting specialist bees, that contains 144 species, mostly neotropical in distribution (Frankie et al. 1988, Michener 2000). Oil plants and their specialized pollinators are important but 
uncommon components of pine rockland communities; this relationship is perhaps more well-represented in other neotropical dry forests and savannahs (Buchmann 1987). Female oil bees land on the center of the flower, and pollen adheres to the hairy underside of the thorax as they scrape the oil glands to collect oil; pollen is then transferred to the stigmas of other flowers (Anderson 1979, Frankie et al. 1988, Michener 2000). Many oil producing plants in the Family Malpighiaceae, including Byrsonima species, have a special type of 'wet' stigma, where a secretion accumulates under the cuticle and is released by mechanical means when the stigmatic is ruptured by the pollinators (Anderson 1979, Sigrist \& Sazima 2004). The hairy thoraxes of oil bees probably aid in the rupturing of the stigmatic surface of these plants. Female Centris bees collect, modify, and use floral oils to line their brood cells (Buchmann 1987) and both the floral oils and floral nectars are essential for their reproduction. The newly invasive oil collecting bee, C. nitida is native to tropical regions of Mexico, Central America, and South America (Snelling 1984). It was first collected in Fairchild Tropical Botanic Garden in Coral Gables, Florida in 1997 and in 1998 in the Rockdale Pineland Preserve, but was originally misidentified as the native Centris lanosa, native to northern Florida and the southwestern United States. The specimens were later correctly identified as $C$. nitida by Pemberton and Liu (2008b).

What was thought to be C. lanosa was observed to visit flowers of the rare endemic pine rockland plant, Byrsonima lucida (Koptur 2006). Commonly known as the locust berry, it is the only member of the tropical plant family Malpighiaceae native to southern Florida. The B. lucida flowers, like other plants in the family, offer oils as a pollinator reward, which are collected by Centris errans (Koptur 2006), the sole native 
pollinator, and only Centris species native to southern Florida (Pemberton \& Liu 2008b). Flowers offering oil reward in southern Florida are found in two families, six genera, and nine species, of which only B. lucida is native (Pemberton \& Liu 2008b). The flowering period of B. lucida is from March to May each year, and coincides with the annual flight period of $C$. errans. In contrast, $C$. nitida flights occur year around, but are seemingly more active in the spring and summer than at other times of the year. We know that $C$. nitida is more active compared to the native Centris in garden sites, has invaded native pine rocklands, and is potentially pollinating native plants (Koptur 2006, Pemberton \& Liu 2008b), but the precise impacts of this introduced oil-collecting bee on native ecological processes is not understood. 


\section{Methodology}

\section{Selection of Study Sites}

Florida pine rocklands are considered critically endangered habitat by the IUCN and a priority eco-region for global conservation (Olson \& Dinnerstein 2002). Pine rocklands are found in the extremes of southern Florida and the Bahamas, and are known to harbor more endemic species than any other habitat in the region (Lodge 2004). Currently these habitats are under increasing pressure from habitat degradation and invasive species. Areas occupied by the rocklands (pinelands and hardwood hammocks) have never been large (Fig 1). Expansion and development of the metropolitan MiamiDade area have led to rapid shrinking and fragmentation of this rare habitat (Snyder et al. 1990; Fig. 1). Today, it is estimated that less than $2 \%$ of the original southern Florida pine rocklands currently remain (Snyder et al. 1990, Koptur 2006). The extent of habitat loss and fragmentation is threatening or endangering a large number of species, especially endemics, as well as disrupting ecosystem processes. When combined with habitat fragmentation, the impacts from non-native and invasive species on rare species are potentially magnified (Didham et al. 2007).

The previously known distribution of $C$. nitida was patchy, occurring in several small fragmented pinelands in Miami-Dade County, but absent from several larger fragments, including the relatively intact pine rocklands of the Everglades National Park (Pemberton \& Liu 2008b). I have selected for study four pine rocklands in which only $C$. errans was present: Zoo Miami-Richmond Complex (natural site 2), Larry and Penny Thompson Park (natural site 3), Seminole Wayside (natural site 4), and Navy Wells 
Pineland (natural site 5); and four sites where both C. nitida and C. errans were known to be present: natural vegetation area in Fairchild Tropical Botanic Garden (garden site 1); two residential gardens in Miami-Dade County (garden sites $2 \& 3$ ); and the Rockdale Pineland Preserve (natural site 1) (Figure 1).

Figure 1Map showing residential garden and natural pine rockland study sites in MiamiDade County, Florida.

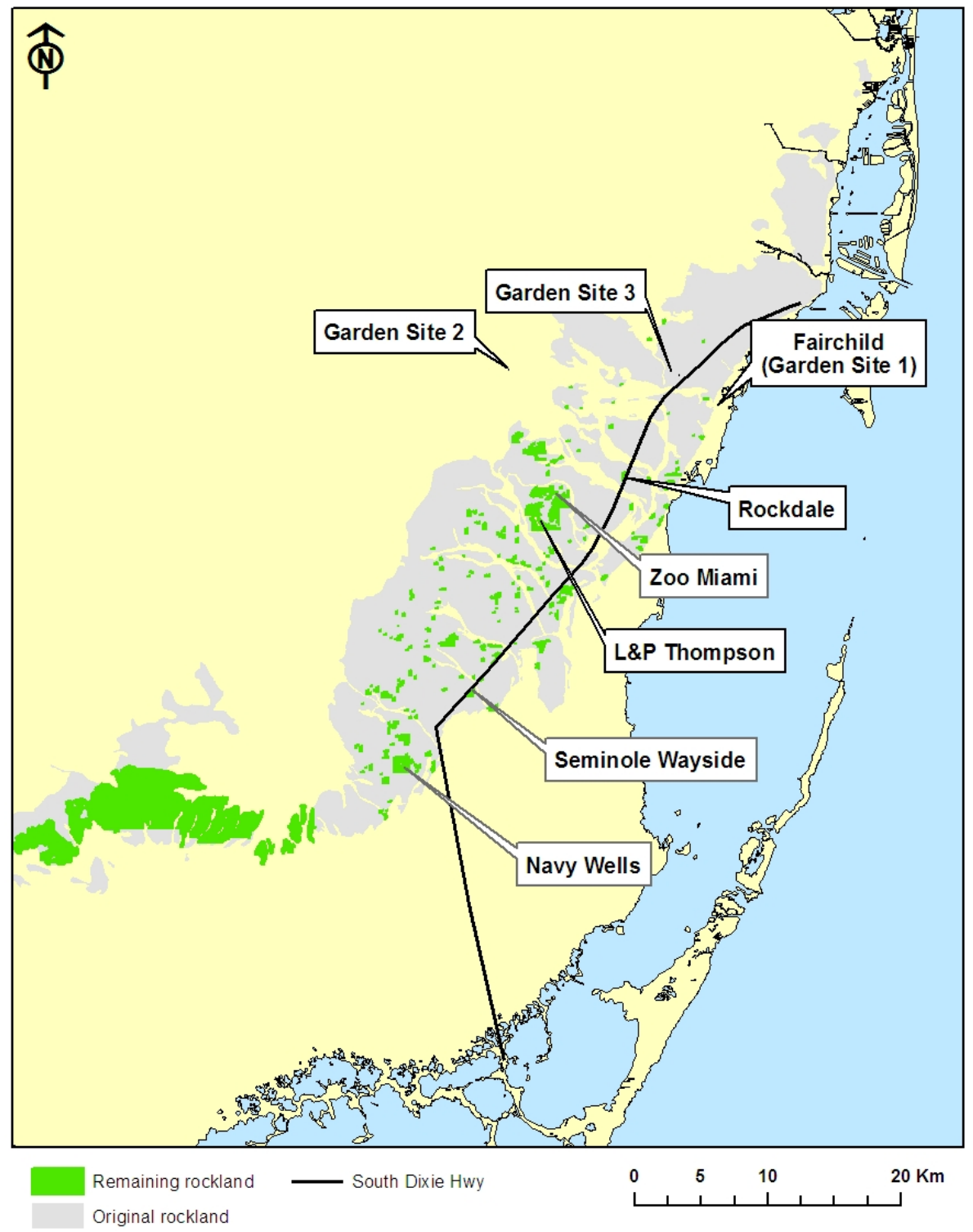




\section{Stigma Receptivity}

Determining the timing and duration in which the stigmas are most receptive (capable of germination) is a necessary to ensure success in breeding system and artificial pollination treatments. Stigma receptivity is a vital phase in the maturation of flowers and can greatly influence the rate and success of pollination at different stages of the flowers life cycle (Dafni 1992). Byrsonima lucida flowers have three color phases, first white, then pink, and finally red. To test in at which color phase the stigmas were most receptive, I used a peroxidase test paper (Peroxtemo KO) solution. Cuttings of several inflorescences containing flowers of all three colors (white, pink, and red) were carefully collected from three different plants at garden site 1. To ensure the stigmas remained viable, the fresh cuttings were immediately taken to the laboratory for analysis. The anthers of each flower type were carefully removed (emasculated) using a dissecting microscope, leaving only the exposed stigmas. The reagent was prepared by macerating two pieces of the test paper in $2 \mathrm{ml}$ of distilled water. Each flower was then placed on a slide and its stigmas were submerged in a droplet of the dilute solution for 2-5 minutes at approx $25^{\circ} \mathrm{C}$, and observed using a dissecting microscope. Initially the reagent remains colorless but changes to blue when it comes into contact with the peroxidase enzyme that is produced inside the stigmatic tissues. Stigmas showing active enzyme production are considered to be "receptive" and turn blue. Each color of flower was tested (white $\mathrm{n}=11$, pink $\mathrm{n}=7$, and red $\mathrm{n}=11$ ). Receptivity was scored as follows; 0 (negative response) or 1 (positive response). The differences in the receptivity of the three different color flowers were compared using a logistic regression and Cox \& Snell $\mathrm{R}^{2}$ analysis. 


\section{Breeding System}

To establish the breeding system of $B$. lucida, I performed the following four pollination treatments on selected flowers: 1) control (unbagged/open pollination); 2) pollinator exclusion (inflorescences bagged to exclude pollinators); 3) artificial selfpollination (flowers bagged and hand-pollinated with pollen from a different flower on the same plant); 4) artificial outcross-pollination (flowers bagged and hand-pollinated with pollen from a flower of different plant). Flowers that had opened prior to the treatments were removed before the treatments were applied. After 7-10 days, each inflorescence was checked for flowers with any resulting fruit set (presence of swollen ovaries or fruit). Pollen was then artificially supplemented by carefully removing the anthers of a donor plant with fine tipped forceps and gently placing a pollen load directly on the stigmatic surface of the recipient flower. The control treatment was used to measure the pollination rate of B. lucida under natural conditions. Under this treatment, unopened flowers were labeled, left un-manipulated, and their resulting fruit sets quantified. I carried out the control treatments on 10 flowers (paired with pollen supplementation treatments, see "pollen limitation" section) on 3 or 4 plants once a week, for at least three replications on each plant at seven sites; garden site 1 and all five natural sites. Because flowers are small and clustered closely together, bagging individual flowers was not feasible. To determine the dependency of B. lucida on pollinators for fruit set, several inflorescences containing unopened flowers were covered with a fine mesh bag to exclude all insect foragers (pollinator exclusion treatment), after 7-10 days remaining flowers are checked for fruit set and any dead or fallen flowers are counted. A 
successful fruit set under pollinator excluded conditions would suggest $B$. lucida is capable of spontaneous self-pollination or apomixis and therefore pollinator dependent. Pollinator exclusion treatments were conducted on four plants at garden site 1 (approx. 512 flowers), and two plants at garden site 2 (approx. 161 flowers) with each bag constituting a replication. To establish whether self-incompatibility exists in $B$. lucida, artificial self-pollination and artificial outcross-pollination treatments were conducted. I hand-pollinated recently opened pairs of fresh flowers, that had opened inside the bags, using either pollen from same plant (self treatment) or pollen from a different donor plant (outcross treatment). To obtain virgin flowers, inflorescences were selected ahead of time just before flowers had opened, and covered with a fine mesh to prevent visits to the newly opened flowers. Pollen source plants were at least one meter apart at the garden sites. The treated flowers were then re-bagged for at least 7 days to exclude additional visits and pollen deposition. Guided by the results of the stigma receptivity tests, only the younger white flowers were selected for artificial pollination treatments. Self and outcross treatments were performed on three plants at garden site 1 and two plants at garden site 3; for each plant, ten paired flowers (one self and one outcross) were treated, and constituted one replication. One-way ANOVA was used to determine the differences in mean fruit set among all of the treatments performed at garden site 1, and post hoc pair-wise comparisons were made using Tukey HSD tests. To boost sample size, self and outcross treatments conducted at garden site 3 were also included in the analysis and then analyzed again using one-way ANOVA. 


\section{Pollen Limitation}

Because B. lucida relies on bee pollinators for fruit set, pollen limitation is a good indication of pollinator limitation (Dafni 1992). To determine the degree of pollen limitation in B. lucida, I artificially supplemented pollen from a donor plant to one of two flowers that were located in similar positions on the inflorescence of a recipient plant (pollen supplement treatment) and left the other flower un-manipulated (control treatment); the inflorescences were not bagged, and open to visitors. If the resulting fruit set of the pollen supplementation treatment is greater than the control treatment then this suggest some degree of pollen limitation.

Pollen was added using the same methodology as previously stated. Pollen source plants were at least 1 meter apart at garden sites, where the number of plants was limited, and at least 5 meters apart in the natural sites, to increase the chance of out-crossing. The presence of swollen ovaries or immature fruit 7-10 days after pollen treatment represented fruit set. Aborted flowers resulted in dried, wilted or dropped flowers. I conducted the pollen supplementation treatments on 10 pairs of flowers, on three or four plants once a week, for at least three replications at six sites (garden site 1 and all five natural sites).

Fruit set was calculated for both treatments as: (total fruit set of the treatment) / (total number of flowers treated) (Dafni 1992). Fruit sets were averaged for each plant and for each site, and each pair of ten flowers per treatment constituted a replicate in the analysis. One-way ANOVA was used to analyze the differences in fruit set of the two treatments (pollen supplementation and control) for six sites (garden site 1 and natural sites 1-5). I also compared the differences in fruit set of the two treatments for sites with 
C. nitida (invasive oil bee) (garden site 1 and natural site 2) and without the invasive oil bee (natural sites 3-5). To test whether pollen limitation differ between sites with and without the invasive oil bee, I grouped sites into two new categories. To accomplish this I created a new variable 'site type' with two levels; sites with the invasive oil bee and sites without. Two-way ANOVA was also used to analyze interaction effect of site type on degree of pollen limitation (difference in fruit set between control and pollen supplement treatments).

\section{Pollination Efficiency}

The efficiency with which the native and invasive oil bees can successfully pollinate $B$. lucida was determined by exposing virgin flowers to a single visit by one of the two bee species (bee treatments) and then comparing each resulting fruit sets. Bee treatments were obtained by bagging flower buds with a fine mesh bag a few days before they opened. After they opened, and during times of bee activity, I removed the bag and allowed only a single visit by a single bee species. Following the visitation event, the flowers were quickly labeled and then re-bagged to prevent any further visitations; fruit set was checked after 7-10 days. Pollination efficiency treatments were conducted on three days during the peak flowering period (May 2010) at garden site 1 where both bees were commonly seen. For the invasive oil bee treatments, six replicates (inflorescences) and a total 51 flowers were treated, and for the native oil bee, nine replicates and a total of 49 flowers were treated. Each replicate was an entire bag that contained the inflorescences visited by the same species. Since all bee treatments were captured at garden site 1, the results of bee treatments were included into the statistical analysis for 
all pollination treatments conducted at garden site 1. Differences in mean fruit sets between the two bee treatments, was compared using the post hoc Tukey HSD tests.

\section{Pollinator Observations}

Timed floral watches were conducted to determine the visitation frequency and visitation rate of various visitors to B. lucida plants at seven sites. In four sites, only the native oil bee occurred (natural site 2-5), and at three sites both native and invasive oil bee were previously known to occur (garden sites 1 and $2 \&$ natural site 1 ) (Pemberton and Liu 2008b). Two of the study sites are non-natural areas (garden sites 1 and 2) and five study sites are natural pine rockland areas (natural sites 1-5). The watches were carried out from the end of April to the end of May 2010 at garden sites 1 and 2 (because of earlier flowering at these two locations), and in May 2010 for all other study sites. The watches were concentrated in the month of May because in most of the natural area study sites it was the peak of the short flowering period of B.lucida. I observed that there was continuous, but variable, forager activity throughout the daylight hours at each site, with increases in activity following rain or cooler temperatures. Therefore, visitor watches were conducted throughout the day (8:30A-4:30P) at each site. At the natural site 2 and natural site 4 , I was unable to conduct watches between 1:00P-4:30P because of frequent and persistent rain during sampling days.

At garden sites 1 and 2 there were only 10 and 5 specimens of B.lucida respectively, and at both sites these individual plants have been allowed to grow beyond a small shrub (their predominate form in natural areas) and into small and large trees. One specimen at garden site 1 exceeded $20 \mathrm{ft}$ in height and typically had more than ca. 1500 
open flowers each watch day. Before timed watches could be preformed, the total display size (total number of flowers on each plant) was quantified. If the plant had more than approximately 200 flowers, a portion of the plant was selected for observation and that flower count was also recorded. Display sizes for plants in the non-natural areas ranged from 35-1500 flowers. In the natural area study sites, plants were far more abundant but much smaller likely because of a combination of poor-nutrient soil, rocky substrate, competition with other plants, and the high frequency of fire in pine rockland habitat. Display sizes for plants in the natural areas ranged from approximately 8-150 flowers, with the exception of one large specimen (>800 flowers) in natural site 1 . The single individual with 800 flowers was at natural site 1 and was located in the unburned and disturbed portion of the preserve. Plants selected for watches were randomly chosen and were distributed throughout the study site. Because of the frequent forager visitation and higher plant abundance in the natural areas, each plant was watched for only 15 minutes in order to sample a larger area of the study site. Following each 15 minute watch, another plant was randomly selected and also watched for $15 \mathrm{~min}$. This was repeated at least four times for a total of one hour of watching per day of sampling, and often there was more than one person collecting data at a time, with each person watching a different plant or patch. We quantified visitation frequency by recording the type and number of visitors in the 15 minute time intervals, and (if possible) the duration of each visitor on the plant. When possible, we also attempted to quantify the number of flowers each bee visited during the visitation.

Floral visitors were identified to species in most cases. The naturalized Centris bee is readily distinguished from the native bee by its smaller size and its distinct bright 
yellow thorax and jet black abdomen. Minor visitors were also identified and included in the study; European honey bees (Apis mellifera), and halictid (Augochlora spp.) bees which were identified by their small metallic blue bodies. Butterflies were simply categorized in the order Lepidoptera. Voucher specimens were collected for C. errans, $C$. nitida, and halictid bees during non-watch periods. To compare the sizes of the bees, thorax width between wings were measured to the nearest $0.01 \mathrm{~mm}$, using a dissecting microscope. Voucher specimens are currently deposited at Fairchild Tropical Botanic Gardens in Miami, Florida.

\section{Visitation Rates}

To capture the differences in visitation frequencies of the two bees, I utilized a visitation rate variable (Dafni 1992). The visitation rate variable was calculated by the formula: (number of visits) / (number of flowers * amount of watch time in minutes) and was completed for both native and invasive oil bees and the other visitors group (all other floral visitors). Differences in the mean visitation rates for each of the three types of floral visitors was compared using one-way ANOVA and was pooled among all sites.

\section{Foraging Rates}

Foraging rates were used to estimate overall foraging behavior/bee activity during visits on an individual plant. The foraging rate was calculated as: (number of flowers visited/ per unit of time). Foraging rates were calculated as: number of flowers visited/ time unit (minutes). Because the foraging rate of insects is often temperature dependent, I collected data for both species at the same time and on the same plant whenever possible. 
Variation in foraging rates we analyzed using one-way ANOVA and pair-wise comparisons was made using post-Hoc Tukey HSD tests. 


\section{Results}

\section{Breeding System and Pollinator Efficiency}

Results of the stigma receptivity tests showed that the youngest (white and pink) flowers are the most capable of germination (Figure 1). White and pink flowers were found to significantly more receptive than red flowers $\left(\mathrm{r}^{2}=0.516, \mathrm{P}=0.009\right)($ Table 1 and 1a). The results of breeding system treatments demonstrated that B. lucida was pollinator dependent and appeared to be self-incompatible. None of the pollinator exclusion treatments (bagged treatment) $(\mathrm{N}=4$ replicates over 450 flowers total) or self pollination treatments (self + treatment $)(\mathrm{N}=3$ replicates over 30 flowers total) successfully set fruit (Figure 2). When outcrossed pollen was artificially added (outcross+ treatment) ( $\mathrm{N}=3$ over 30 flowers total) flowers did successfully set fruit with a mean fruit set of $29 \%$ (Figure 2). Most likely because of the limited number of replications conducted at garden site 1, post hoc Tukey test revealed no difference in fruit set between self pollination and outcross treatments $(\mathrm{P}=0.585)$ (Appendix 1). When the data from garden site $3(\mathrm{~N}=3$ replicates over 30 flowers total), all of which also failed to set fruit, were included into sample pool, one-way ANOVA indicated a difference in mean fruit set between the self and outcross treatments $\left(\mathrm{F}_{(1,8)}=5.828, \mathrm{P}=0.042\right)$ (appendix 2). Coupled with the fact that none of the self treatments set fruit, further supports the conclusion that $B$. lucida is self-incompatible. Mean fruit sets were different among the various pollination treatments at garden site $1\left(\mathrm{~F}_{(6,31)}=3.939, \mathrm{P}=0.005\right.$; Table 2). Artificial pollen supplementation treatments (pollen supplement treatment) yielded the highest fruit set of $51.7 \%(\mathrm{~N}=5$ replicates over 50 flowers total) (Figure 2) of all 
treatment types, but post hoc Tukey post tests indicated no difference in fruit set between the other pollination treatments, except for the pollinator exclusion treatment (appendix 1). Flowers visited by the invasive oil bee (C. nitida treatment) had a mean fruit set of $50.21 \%(\mathrm{~N}=6$ replicates over 50 flowers total $)$ and was higher than the mean fruit set by the native oil bee (C. errans treatment) with a mean fruit set of $29.38 \%(\mathrm{~N}=9$ replicates over 45 flowers total) (Figure 2). Tukey post hoc pair-wise comparison indicated there was no difference in fruit set between the two bee treatments $(\mathrm{P}=0.541)$ (appendix 1), again mostly likely as a result of the lack of replications. However the percent fruit set produced, in these limited replications, still suggests that the invasive oil bee is a more efficient pollinator of $B$. lucida than the native oil bee.

Figure 2. Bar graph showing the percentage of flowers that scored positive for stigma receptivity for three color phases of Bysonima lucida flowers. $\mathrm{N}=$ number of flowers and each flower represents a replicate.

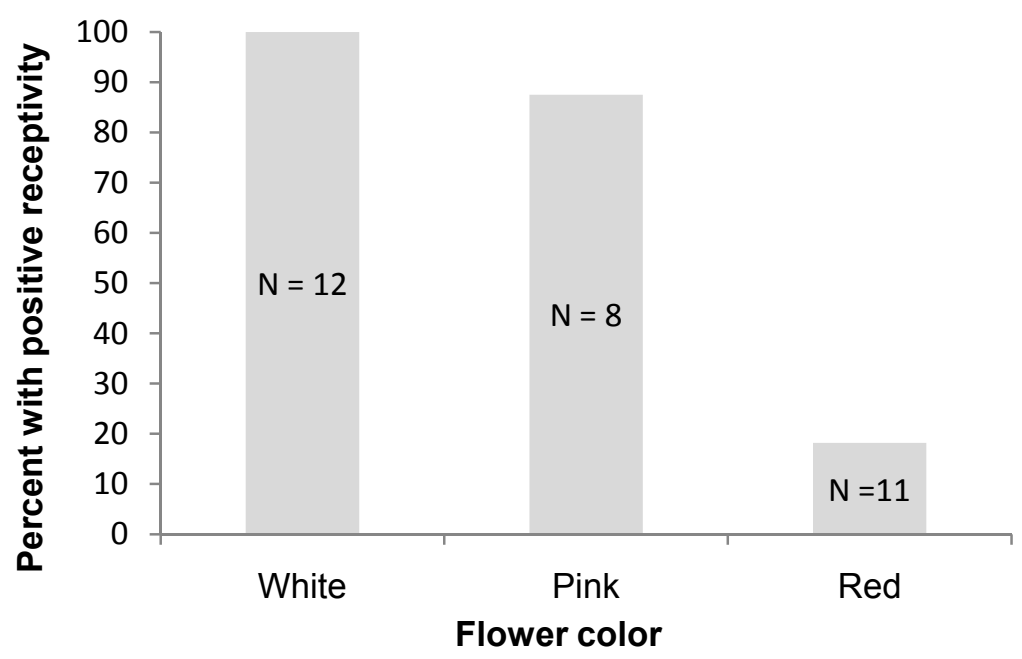


Table 1. Logistic regression tables showing mean differences in receptivity scores $(0=$ negative score $\& 1=$ positive score $)$ for white, pink, and red flowers.

\begin{tabular}{|l|r|r|r|}
\hline Step & -2 Log likelihood & Cox \& Snell R Square & Nagelkerke R Square \\
\hline 1 & $16.459^{\mathrm{a}}$ & .516 & .722 \\
\hline
\end{tabular}

\begin{tabular}{|l|r|r|r|r|r|r|}
\hline & \multicolumn{1}{c|}{ B } & \multicolumn{1}{c|}{ S.E. } & \multicolumn{1}{c|}{ Wald } & df & \multicolumn{1}{c|}{ Sig. } & Exp(B) \\
\hline Step 1 $1^{\mathrm{a}} \quad$ White Flowers & & & 6.786 & 2 & .034 & \\
Pink Flowers & 22.707 & 11602.711 & .000 & 1 & .998 & $7.270 \mathrm{E} 9$ \\
Red Flowers & 3.450 & 1.324 & 6.786 & 1 & .009 & 31.500 \\
Constant & -1.504 & .782 & 3.702 & 1 & .054 & .222 \\
\hline
\end{tabular}

Figure 3. Comparison of the mean fruit set by Byrsonima lucida for all pollination treatments at garden site 1 (Fairchild Garden). The treatments "Centris errans" and "Centris nitida" were single visits by only one bee to the flower. At this site Centris errans was the dominant floral visitor. $\mathrm{N}=$ indicates the number of replicates for each treatment (each replicate consists of at least 10 flowers) and error bars represent standard error (SE) of each treatment.

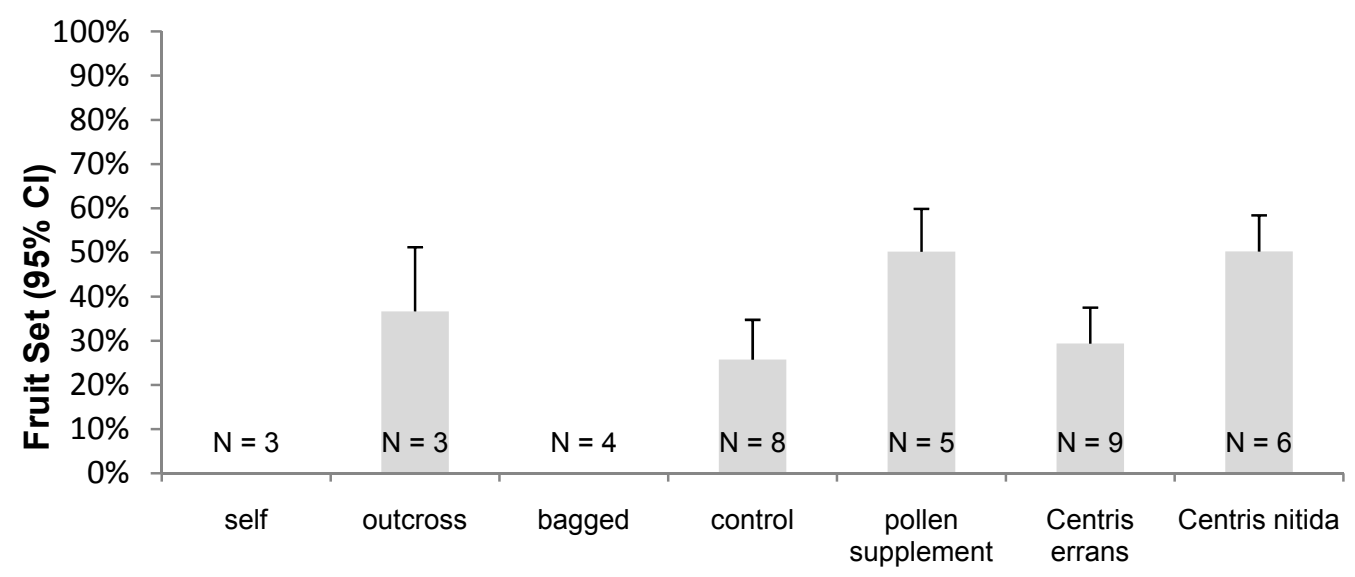

Pollination Treatments 
Table 2. One-Way ANOVA table showing effects of all seven pollination treatments on percentage of fruit sets of Byrsonima lucida in Garden site 1 (Fairchild Garden).

\begin{tabular}{|c|c|c|c|c|c|}
\hline & Sum of Squares & df & Mean Square & $\mathrm{F}$ & Sig. \\
\hline Between Groups & 1.106 & 6 & .184 & 3.939 & .005 \\
\hline Within Groups & 1.451 & 31 & .047 & & \\
\hline Total & 2.558 & 37 & & & \\
\hline
\end{tabular}

\section{Pollen Limitation in B. lucida}

I defined pollen limitation as the increased percentage of fruit set between the pollen supplementation treatment and the control treatment. All study sites showed similar increases in the percentage of fruit set between the two paired treatments (Figure 3). Two-way ANOVA indicated no significant interaction between the pollen limitation treatment and site $\left(\mathrm{F}_{(5,93)}=0.182, \mathrm{P}=0.969\right)$ (Table 3$)$. With all sites pooled, pollen supplementation treatments yielded significantly higher fruit set (mean $\pm \mathrm{sd}$ ) than of the control treatments (mean $\pm \mathrm{sd})\left(\mathrm{F}_{(1,93)}=40.698, \mathrm{P}<0.001\right)$ (Table 3), indicating pollen limitation is occurring at all sites. Moreover, there was no significant interaction between site type (with and without invasive oil bee) and pollen limitation treatment $\left(\mathrm{F}_{(3 \text {, }}\right.$ $\left.{ }_{88)}=0.23, \mathrm{P}=0.879\right)($ Table 4$)$, indicating that the presence of the invasive oil bee did not impact the degree of pollen limitation, as shown by the parallel reduction slops connecting the fruit set of the pollen supplement and control treatment at these two site types (Figure 4). There was a significantly higher percentage of fruit set for pollen supplementation treatments than those for the control treatments for both site types $\left(\mathrm{F}_{(1,88)}\right.$ $=22.894, \mathrm{P}<0.001)$ (Table 3). 
Figure 4. Bar graph comparing mean fruit set for control and artificial pollen supplement treatments for at least three plants of Byrsonima lucida at one garden site and five natural pine rockland sites in extreme southern Florida. $\mathrm{N}=$ number replicates for each treatment (each replicate consists of at least 10 flowers) and error bars represent the standard deviation $(\mathrm{SD})$ of each treatment.

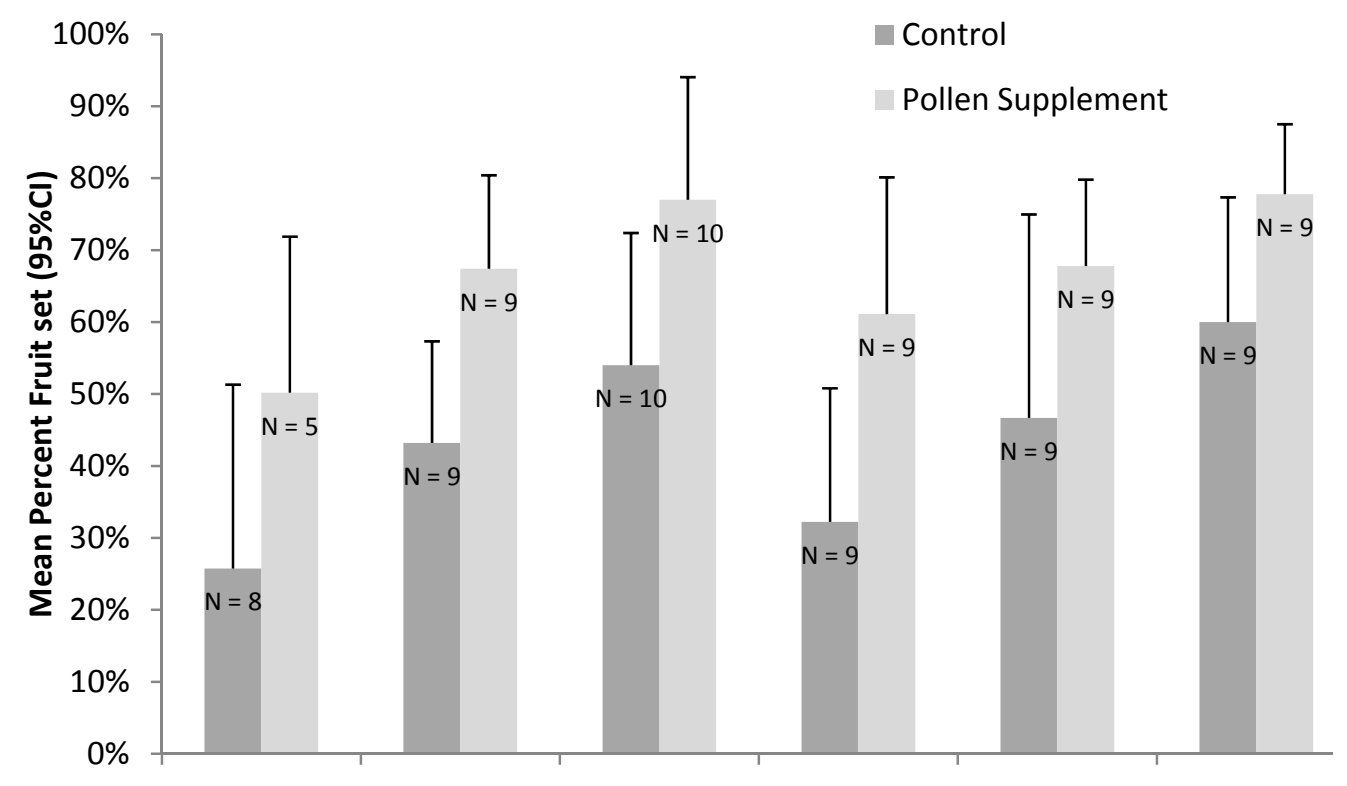

Garden Site 1 Natural Site 1 Natural Site 2 Natural Site 3 Natural Site 4 Natural Site

Study Sites

Table 3. Two-way ANOVA table showing the interactions between two pollination treatments (control and pollen supplement) and garden versus natural sites on mean fruit set.

\begin{tabular}{|l|r|r|r|r|r|}
\hline Source & $\begin{array}{r}\text { Type III Sum of } \\
\text { Squares }\end{array}$ & df & Mean Square & F & \multicolumn{1}{c|}{ Sig. } \\
\hline Corrected Model & $2.635^{\mathrm{a}}$ & 11 & .240 & 7.095 & .000 \\
Intercept & 31.097 & 1 & 31.097 & 920.878 & .000 \\
trt & 1.374 & 1 & 1.374 & 40.698 & .000 \\
Site & 1.039 & 5 & .208 & 6.153 & .000 \\
trt * Site & .031 & 5 & .006 & .182 & .969 \\
Error & 3.141 & 93 & .034 & & \\
\hline
\end{tabular}




\begin{tabular}{|l|r|r|r|} 
& 38.618 & 105 \\
Corrected Total & 5.776 & 104 & \\
\end{tabular}

Figure 5. Comparison showing there are no differences in the reduction of the percentage fruit set of Byrsonima lucida between the control and pollen supplementation treatments in natural sites with and without the invasive oil bee Centris nitida.

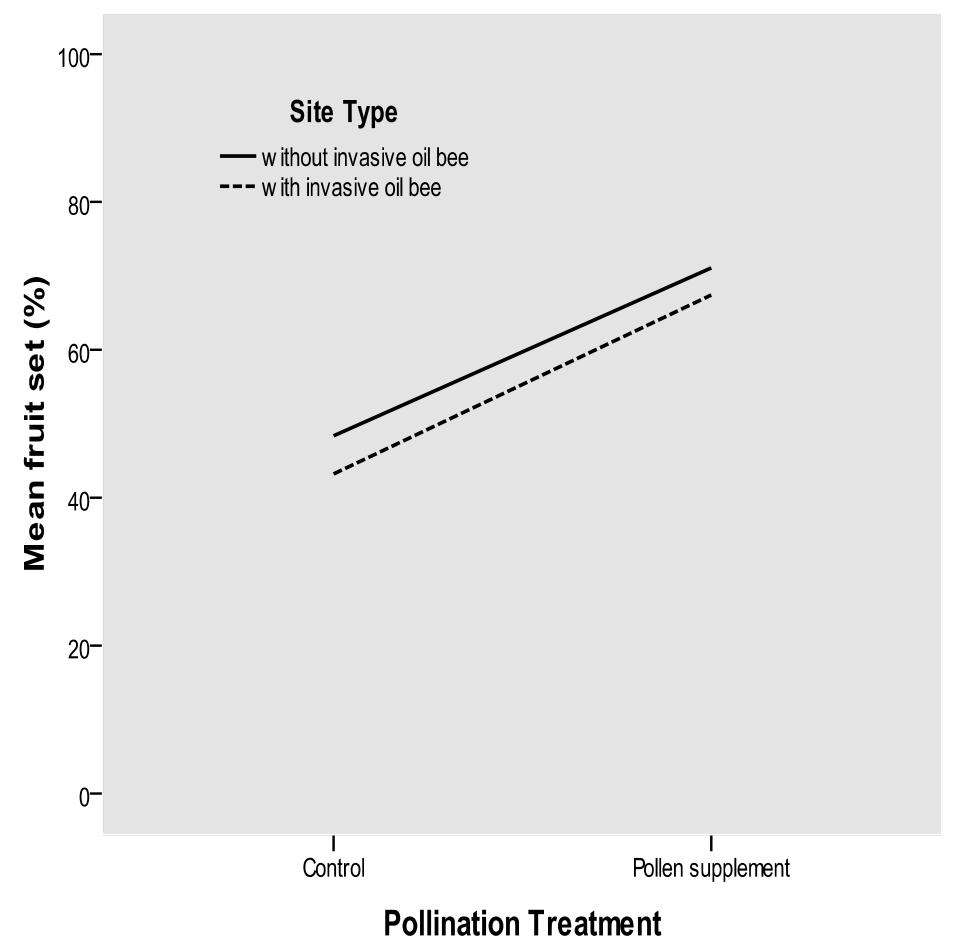

Table 4. Two-way ANOVA showing interactions between two pollination treatments (control and pollen supplement) and sites with and without the introduced bee on mean fruit set.

Two-way ANOVA showing interactions between two pollination

\begin{tabular}{|l|r|r|r|r|r|}
\hline Source & $\begin{array}{c}\text { Type III Sum of } \\
\text { Squares }\end{array}$ & df & Mean Square & \multicolumn{1}{|c|}{ F } & Sig. \\
\hline Corrected Model & $1.245^{\mathrm{a}}$ & 3 & .415 & 11.936 & .000 \\
Intercept & 19.160 & 1 & 19.160 & 550.947 & .000 \\
\hline
\end{tabular}




\begin{tabular}{|c|c|c|c|c|c|}
\hline trt & .796 & 1 & .796 & 22.894 & .000 \\
\hline site_cat2 & .028 & 1 & .028 & .814 & .369 \\
\hline trt * site_cat2 & .001 & 1 & .001 & .023 & .879 \\
\hline Error & 3.060 & 88 & .035 & & \\
\hline Total & 36.184 & 92 & & & \\
\hline Corrected Total & 4.306 & 91 & & & \\
\hline
\end{tabular}

\section{Pollinator Observations}

I carried out a total of 31 hours (1860 minutes) of watch time with a minimum of 165 minutes at each site and at least 15 minutes at each plant (Figure 5). The invasive oil bee was found to be present in garden site 1, garden site 2 and natural site 1 (Figures 5 a,b,c), while apparently absent in all other study sites (natural sites 2-5) (Figures $5 \mathrm{~d}-\mathrm{h}$ ). Observations indicate that the native oil bee was the most frequent visitor at all study sites because of the larger proportion of watch minutes it occupied in comparison to all other floral visitors. Among all sites pooled, native oil bee visits constituted $21 \%$ of the total watch time to flowers of $B$. lucida, while the invasive oil bee visits made up only $2 \%$ of the total watch time, with less than $2 \%$ overlap (duration when both bees are visiting), and "other" visitors were observed less than $1 \%$ of the total watch time (Figure 5a). The "others" group, comprised mostly of honey bees (Apis mellifera), showed little interest and were not observed collecting pollen, only briefly landed on flowers and quickly departed. At natural site 2 and natural site 4, Halictid bees (Augochlora spp.) were also observed to occasionally visit $B$. lucida $(<1 \%$ total watch time at each site) (Figures $5 \mathrm{c} \& \mathrm{~g}$ ), but they were found to collect pollen from flowers, and could only be 
minor pollinators of B.lucida. It is unknown whether any of the flowers visited by Augochlora spp. successfully set fruit. Garden site 1 was found to have the most pollinator activity, with the highest proportions of watch time occupied by both the native and invasive oil bees, $56 \%$ and $6 \%$ respectively, and the highest proportion of time when both bee species were visiting simultaneously "overlap" $(8 \%)$, for nearly $71 \%$ of the total watch time at garden site 1 there was some bee activity (Figure $5 b$ ). During these "overlap" periods there was very little direct contact or competition for floral resources between the two bee species, the few infrequent interactions observed were mostly nonaggressive and similar to the interactions among different individuals within the same species. In garden site 2 native oil bee and invasive oil bee proportion of time occupied was most similar, $10 \%$ and $4 \%$ respectively; with $2 \%$ overlap (Figure $5 \mathrm{c}$ ). In study sites where only the native oil bee was observed, the proportions of watch times occupied by the floral visitor were very similar, constituting $9-12 \%$ of the total watch times at each site, less than the proportion of watch time occupied by native oil bees in the sites where both bees co-occur (Figure 5). In addition, in sites where both bees do co-occur, the amount of time watched when no floral visitors were present was greatly reduced. This may be because these particular study sites were either non-natural areas (garden sites 1 and 2) or the fire suppressed natural area (natural site 1) all of which had fewer individual plants with much larger display sizes as compared to individuals found in a natural fire maintained pine rockland communities (natural sites 3-5) and where located within close proximity to residential areas, suggesting higher ornamental plant availability as well. 
Figure 6. Pie chart showing the amount of time watched and the proportion of time occupied by each floral visitor to Byrsonima lucida among all study sites pooled (a), garden sites (b \& c), and natural pine rockland sites (d-h) in extreme southern Florida.
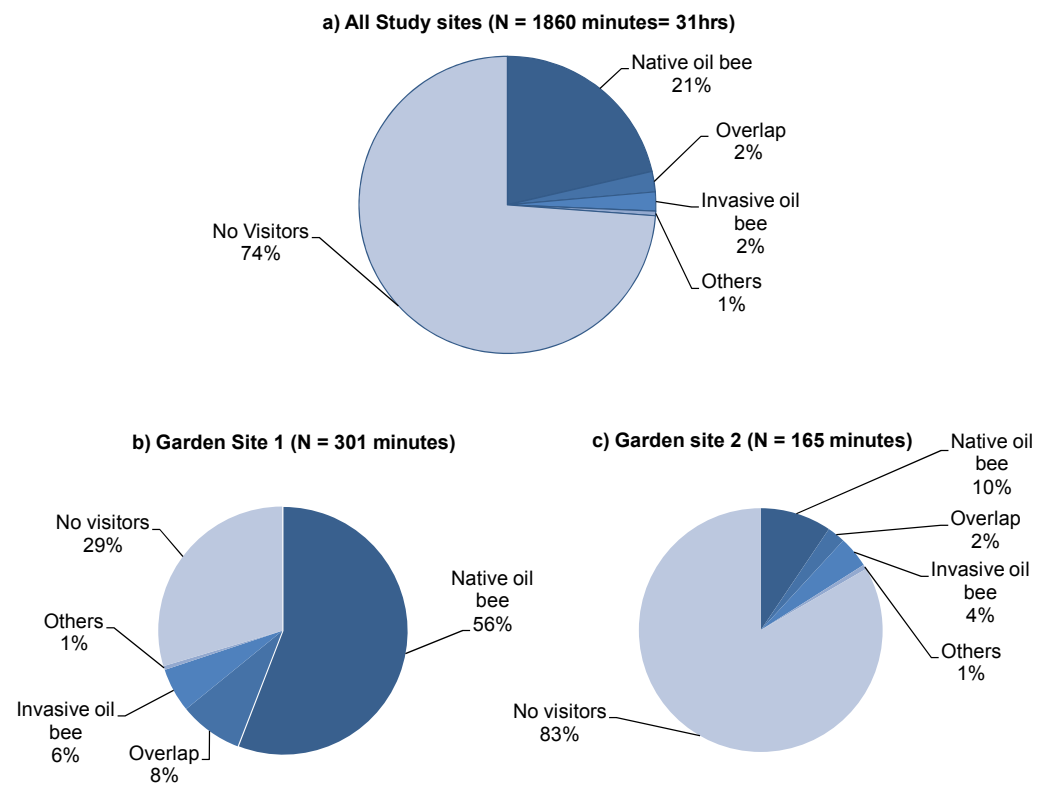

d) Natural Site 1 ( $N=180$ minutes)

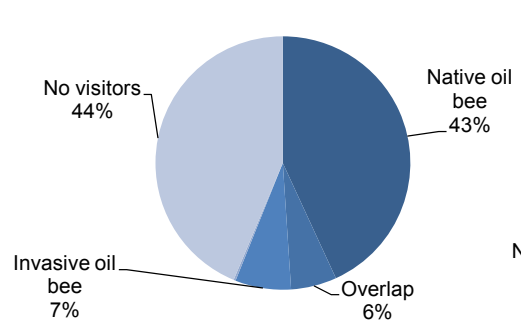

f) Natural Site 3 ( $N=270$ minutes)

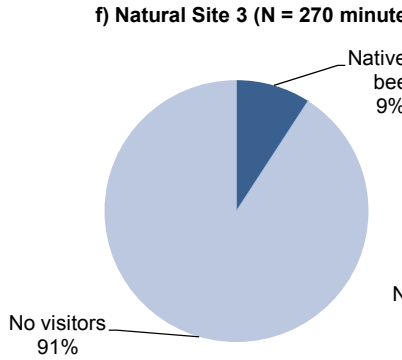

e) Natural Site 2 ( $N=390$ minutes)

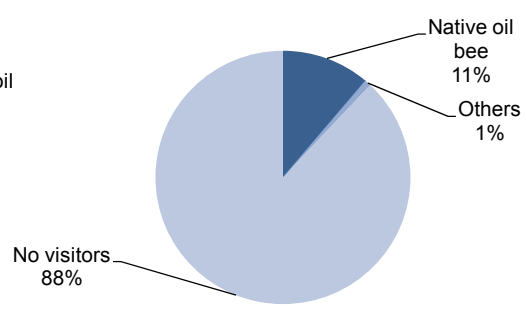

g) Natural Site 4 ( $N=225$ minutes) h) Natural Site 5 ( $N=330$ minutes)

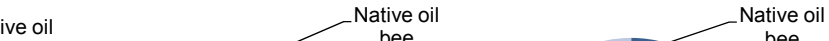
bee
$9 \%$ $12 \%$

Others

$1 \%$

No visitors

$91 \%$ 


\section{Visitation Rates}

Visitation rates (number of visits / number of flowers * amount of watch time in minutes) of the native oil bee were significantly higher that of the invasive oil bee which was observed to be an infrequent visitor to B. lucida (Figure 6). There was a difference in the visitation rates of the three different types of floral visitors (native oil bee, invasive oil bee, and other visitors $)\left(\mathrm{F}_{(2,375)}=34.061, \mathrm{P}=<0.001\right)$ (Table 5). Tukey post hoc pairwise comparisons indicated a difference in the visitation rates between the native oil bee and the invasive oil bee $(\mathrm{P}=<0.001)$ but no difference between the visitation rates of the invasive oil bees and other minor bee visitors $(\mathrm{P}=0.997)$ (Appendix 3), further supporting that the invasive oil bee is also only a minor visitor to B. lucida.

Figure 7. Comparison of mean visitation rates of three floral visitors to Byrsonima lucida among all study sites pooled. $\mathrm{N}=126$ replications of at least 15 minutes of watching on each plant and error bars represent standard error (SE) of each treatment. "Others" group refers to any non-oil bee visitors.

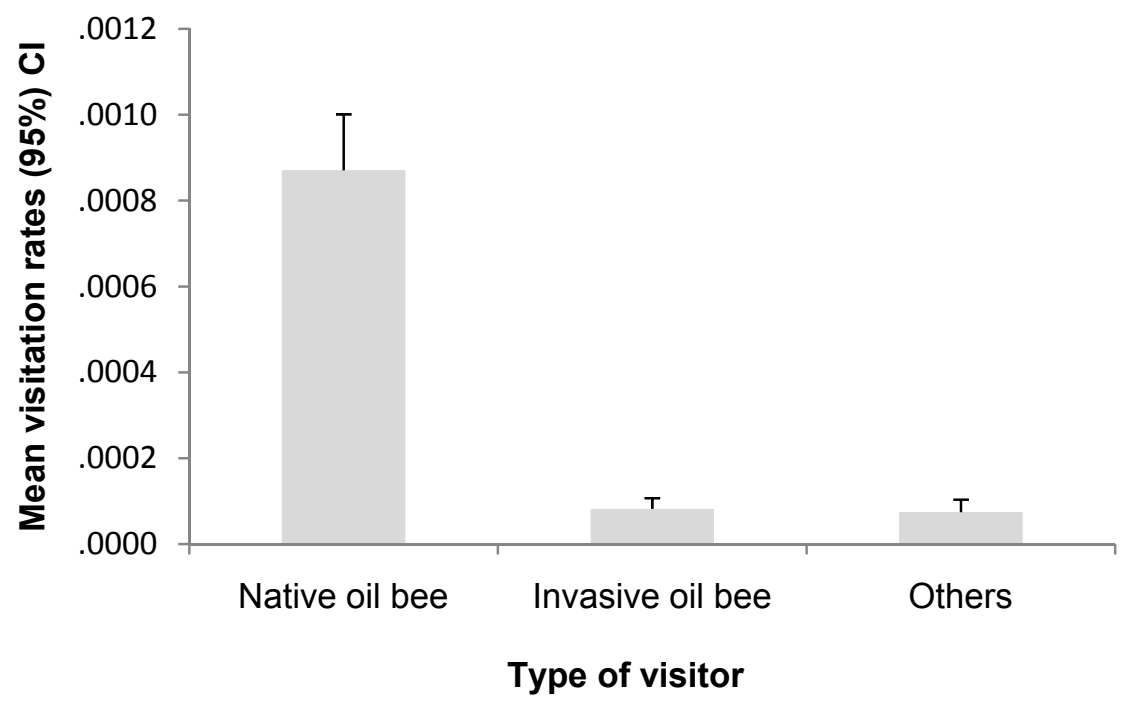


Table 5. One- Way ANOVA table showing the variance in mean visitation rates among three floral visitors to Byrsonima lucida.

\begin{tabular}{|c|c|c|c|c|c|}
\hline & Sum of Squares & $\mathrm{df}$ & Mean Square & $\mathrm{F}$ & Sig. \\
\hline & .000 & 2 & .000 & 34.061 & .000 \\
\hline Within Groups & .000 & 375 & .000 & & \\
\hline Total & .000 & 377 & & & \\
\hline
\end{tabular}

\section{Foraging Rates}

Invasive oil bees visit significantly more flowers per unit of time that do the native oil bees and all other native floral visitors (Figure 7). There was a difference in the foraging rates between the three different types of floral visitors $\left(\mathrm{F}_{(2,196)}=23.187, \mathrm{P}=<\right.$ 0.001) (Table 6). The invasive oil bee was observed to be the most active forager with a mean foraging rate of 22.69 (Figure 7) in comparison to only a 12.31 foraging rate for the native oil bees. Tukey post hoc pair-wise analysis did indicate a difference between the mean foraging rates of the invasive oil bee and native oil bee (Post Hoc Tukey, $\mathrm{P}=$ $<0.001$ ) (appendix 4). As expected, the foraging rates of the floral visitors in the "others" group were significantly lower than that of either of the oil bees (Post Hoc Tukey, $\mathrm{P}=$ $<0.001 \& \mathrm{P}=0.013)$ (Appendix 4). 
Figure 8. Comparison of mean foraging rates of three floral visitors to Byrsonima lucida among all study sites pooled. Error bars represent standard error (SE) of each treatment.

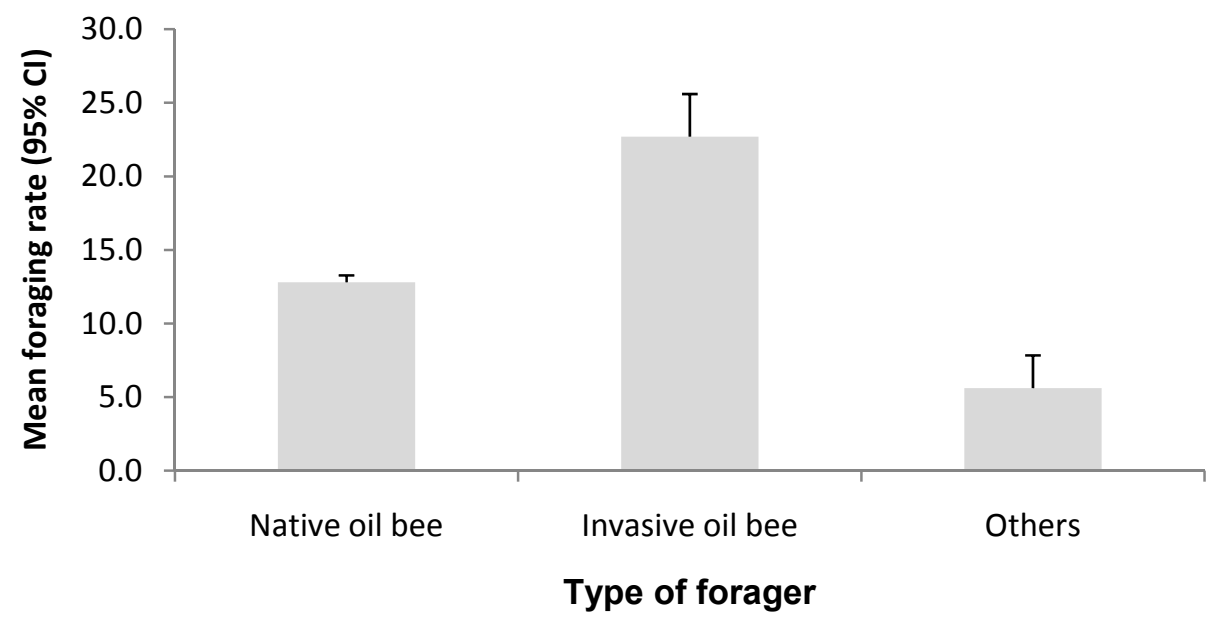

Table 6. One-way ANOVA table showing the variance in mean foraging rates among three floral visitors to Byrsonima lucida.

\begin{tabular}{|l|r|r|r|r|r|}
\hline & Sum of Squares & Df & Mean Square & F & \multicolumn{1}{|l|}{ Sig. } \\
\hline Between Groups & 2500.678 & 2 & 1250.339 & 23.187 & .000 \\
Within Groups & 10569.047 & 196 & 53.924 & & \\
Total & 13069.725 & 198 & & & \\
\hline
\end{tabular}




\section{Discussion}

\section{Current Distribution of $C$. nitida}

Earlier surveys indicated that $C$. nitida was present and common in Rockdale Pineland Preserve and in urban areas throughout Miami-Dade County (Pascarella et al. 1999, Koptur 2006, Pemberton \& Liu 2008b), and is a known visitor to B. lucida (Koptur 2006, Pemberton \& Liu 2008b). However, this study found the invasive bee to be less common than previously described and without a significant expansion in range. The invasive oil bee continued to be present at Fairchild Tropical Botanic Garden (garden site 1) and at Rockdale Pineland Preserve (natural site 1), as well as other residential gardens (garden sites 2 \& 3) in metropolitan Miami-Dade County. Observations made in 1998, stated that the invasive bee was once the more common floral visitor to B. lucida at Fairchild Garden (garden site 1) and other garden settings (Koptur 2006), but during the study period the invasive bee was the less abundant of the two Centris visitors, even among the garden study sites.

The absence of the invasive oil bee in all but one of the natural study sites and its reduced densities in garden study sites may be attributed to the unusually cold dry season in southern Florida in 2009. In contrast, the impacts of this unusually extended cold weather on the native Centris may be minimal because of its ground nesting habits and dormancy during the dry season. Reduction in population size during the sampling period may have resulted in the under estimation of the true impacts of the invasive bee. For $C$. nitida a future population rebound can be expected in urban areas, because the surviving individuals will be hardier and more adapted to withstand these periodic cold events. In 
urban or garden settings, man-made structures, buildings, and green houses, all could have provided shelter during stochastic extreme weather events. In garden sites 2 and 3 (the most residential of the environments studied) the proportion of time occupied by the two bees was the most similar, suggesting more of an impact to the urban populations and further supporting evidence that the invasive bee is more associated with non-natural environments.

Another explanation for the absence of $C$. nitida in most natural pine rocklands may be the lack of appropriate nesting habitat. In their native habitats of Mexico and Central America, female C. nitida build nests in pre-existing holes found in trees, particularly oak species (Frankie et al. 1993). Pine rocklands are fire climax communities and fire can periodically reduce the abundance of understory species and their inhabitants (Lodge 2005), potentially limiting the populations of stem nesting bees. Meanwhile, the native oil bee nests in similar cavities found in the exposed oolitic limestone rock (personal observations 2010) and create there broods deep enough beneath the soil surface to be insulated from the surface fires (Myers \& Ewel 1990). Rockdale Pineland Preserve (natural site 1) was the only natural site where both bees were observed to cooccur. This site is a small remnant pine rockland in which fire has been suppressed (due to its location in a residential neighborhood, adjacent to a major city road), and has been quite disturbed (mechanical removal of exotic pest plants and backfill). Natural site 1 was also the closest in proximity to garden site $1(<10 \mathrm{~km})$ which has a well established population of the invasive bee; immigration from that site was therefore likely to occur.

Because of the availability of oil-producing plants, many of which are ornamentals, in residential gardens such as in garden site 1 (8 oil-producing species) 
(Pemberton \& Liu 2008b), and the availability of appropriate nesting habitat, I conclude that the invasive oil bee in its non-native range is most associated with urban areas and natural areas nearby urban areas. The pine rockland fragments most likely to be invaded are ones that are fire suppressed, near tropical hardwood hammocks, disturbed areas, or residential areas and where ornamental and suitable man-made structures are available for nesting are available.

\section{Behavioral differences between Centris bees and other floral visitors}

There were behavioral differences observed between the native and invasive Centris bees. Invasive oil bees were noticeably faster and more agile than the native oil bee, which was reflected in the significant difference in foraging rates (numbers of flowers visited per minute). Increased activity may allow the invasive oil bee to forage over greater distances and in more dynamic environments. The actual pollinating behaviors (body placement and oil collection) were similar in the two congeners and are typical of most Centris bee species (Anderson 1979).

Although there is no clear agreement on whether introduced pollinators can negatively impact native pollinators, some cases for direct (exploitative) and indirect (interference) competition for floral resources have been made (Dafni \& Shmida 1996, Butz 1997). Direct competition has been observed between European honey bees and smaller native bees through physical disturbance (Gross \& Mackay 1998), but I did not observe any direct competition between the two Centris bees (one bee physically chasing another off of a flower) for flower sites. The few direct interactions were brief chasing of one another while hovering over the plants and were similar to that of intraspecies 
interactions. The lack of direct competition effects may be a result of the abundant floral resource (large display sizes) available on the individual plants at the study sites where the two bees co-occurred, or the low density or absence of the invasive bee at some of the studied sites. Indirect competition through the exploitation of nectar or pollen resources has been demonstrated in bumble bees and honey bees (Paton 1990, Hingston \& McQuillan 1999). In this case indirect competition for the shared floral resource cannot be assumed because; I did observe repeated visitations by foragers to the same flower, oils were continually produced by the same flower over a period of days, and nothing is known about the oil budget of $B$. lucida. Apparent competition between the two bees may have an impact in natural pine rockland sites where potential predators may be more abundant (spiders, predator insects, and parasites), but no obvious shared predators where observed at any site.

At natural sites 2 and 4, Augochlora sp. was observed to visit B. lucida and seem to be capable of collecting the pollen. Augochlora bees were more active when visiting a flower, continually changing angles and body position on the flower, and at some points investing underneath the flower. One specimen of Augochlora was collected from natural site 4 with what appeared to be the pollen grains of $B$. lucida attached to the hind tibia. Auglochlora species are also known to visit the flowers of orchid species which are also specialist pollinated (Pemberton and Liu 2008a). Whether or not Augochlora is capable of pollinating $B$. lucida, which requires rupturing of a film on the stigmatic surface needs to be studies further. Like the oil bees, Augochlora bees did seem interested in the oil reward but it still remains unclear what benefit they gain from the interaction. 
At all sites honey bees were present in the watch areas and showed some interest in the flowers. When investigating a flower or as they probe for nectar or pollen, honey bees placed their heads over the reproductive parts making some direct contact with the anthers or stigma. This body position is in contrast to oil bees which center their bodies on the flower allowing their hair covered thoraxes to make direct contact with the anthers and stigma. It is unknown whether honey bees are capable of transporting pollen, but like the Augochlora bees, they lack the morphological features (coarse hairs on thorax) needed to rupture the stigmatic surface. Future study into the role of honey bees as minor pollinators of B. lucida is still needed.

\section{Promotion of fruit set in $B$. lucida by native versus invasive oil bees}

Both the native and invasive oil collecting bees contribute to the pollination services of $B$. lucida in southern Florida. Where both bees are sympatric, the native oil bee was the more frequent visitor but was outperformed by the invasive oil bee in key pollination processes (pollination efficiency and foraging rate). Foraging rates can have a positive impact on fruit set of $B$. lucida as more active foragers would have better chance of outcrossing (Dafni \& Shmida 1996). Per visit, the invasive oil bee produced a higher mean percentage of fruit set than the native oil bee and was comparable to the artificial pollen supplement treatments. The results suggest that the invasive bee is the more efficient pollinator; the lack of statistical significance in the data analysis is likely a result of the limited number of replications. Though the invasive oil bee is the more efficient pollinator and the more active forager than its native congener, its absence in most natural areas and the infrequent visitations in areas where it does occur, suggests it is only 
a minor pollinator and that the native oil bee remains the major pollinator of B. lucida in natural areas.

Plants showed some degree of pollen limitation at all study sites regardless of the additional pollinator contributions. The ecological consequences of pollen limitation include changes in plant population growth rate, community structure, and ecosystem functioning (Ashman et al. 2004). Sustained and naturally occurring pollen limitation is not rare (Burd 1994b, Knight et al. 2005), especially in native and endemic plants (Ashman et al. 2004). One caveat in estimating pollen limitation is that artificial pollen supplement treatments often provide a better quality of pollen (pure outcross) and higher rate of delivery of pollen than that of natural pollination systems (Knight et al. 2005).

As proposed by Kearns et al. (2008) and Pemberton and Liu (2008b), the reduction in the native pollination services and subsequent increases in pollen limitation may be the result of the native major pollinator being becoming less common than historically, because of the decline in their required floral resources habitat. In this study, Byrsonima lucida is a habitat specialist, and with less than $2 \%$ of the pine rockland remaining (outside of Everglades National Park), in a highly fragmented state, the numbers of this species are undoubtedly much lower than there were historically. The distance between the populations of $B$. lucida may now be greater than the foraging range of the native oil bee, and the remaining isolated populations may not be large enough to sustain historical pollinator population sizes of the native pollinator. If the invasive bee were more abundant it may help reduce the degree of pollen limitation in natural areas, as seen in the case in Hawaii with the endangered vine, Freycinetia arborea (Cox 1983). 
Interestingly, pollen limitation was shown to be most severe at garden site 1, where both bees were present and more active than in the natural study sites. Pollen limitations at garden site 1 could be a result of the larger display sizes (largest plants $>1000$ flowers) of the individual plants at this site, as compared to plants at all other sites. There is evidence that the number of flowers per plant may impact forager behavior (Groom 1998). Indeed, on larger trees, both bee species were able to collect more of the oil resource from a single individual plant and thus increasing the likelihood of self pollination. Pollen limitation was also more severe in study sites where proper fire regimes were not being maintained; in which case individual $B$. lucida attain a larger size and larger floral display than those in sites maintained with periodic fire. Large floral display size, as mentioned above, discourages fruit set in this species because of increased probability of self-pollination. Fire is a necessary disturbance to maintain pine rockland community structure (Lodge 2005) and sites with this disturbance were shown to have a lesser degree of pollen limitation. Natural sites 2 and 5 both had undergone recent prescribed burns (within the last 5yrs) and are located in areas buffered by other protected areas or non-residential areas, respectively. At these sites, plants were more numerous with smaller display sizes (averaging less $<137$ flowers per plant). This could promote outcrossing, thereby reducing the degree of pollen limitation at these sites. One interesting consequence may be, as (and if) the density of the invasive oil bee increases, pollen limitation in B. lucida may be reduced, because this exotic species spends less time on any single plant (higher foraging rates versus native oil bee) and is thus more likely to promote outcrossing than its native counterpart. 


\section{Conclusion}

Introduced specialist pollinators have been previously recognized as new components of pollination webs in Florida (Koptur 1998, Pemberton \& Liu 2008a, Pemberton \& Liu 2008b, Liu \& Pemberton 2009); yet the limited occurrence of the invasive oil bee has kept it from playing a major role in the reproductive success of $B$. lucida, particularly in natural pine rockland sites. These globally imperiled ecosystems are becoming increasingly rare as human populations grow and spread further into natural areas. Habitat losses have led to a decrease in numbers and diversity of oil-collecting bees (Kearns et al. 1998, Koptur 2006) along with the plants that depend on these bees for outcrossing. Apart from the influence of urban development, the acquisition of the pollination services of the invasive oil bee by B. lucida over a large scale is still unlikely, primarily due to the fact that this species is active year round and the required floral resources, in the natural areas, are only available for only three months (flowering period of $B$. lucida). It is more likely that the invasive oil bee is a more important pollinator of non-native or ornamental species in southern Florida, because of the abundance of those species within the range where it occurs, and their availability year round. In the future, C. nitida may also be a small threat to ornamental plant growers, such as orchid farmers, by offering pollinator services that do not normally occur in this area (Florida has no native orchid bees) and thereby reducing the flower duration these economically important species.

Global climate change could potentially benefit the establishment success and persistence of $C$. nitida in southern Florida, as it may become adapted to withstand periodic cold weather events that currently are thought to limit population growth of this 
tropical species; alternatively, warmer weather will eliminate these fluctuations and allow the populations to grow. The continued exchange of peoples and goods between Miami and other tropical parts of the tropics will make new invasions likely, so in the future, more studies that can quantify the contributions of introduced bees on native flora, which can then determine the true nature of novel specialist mutualisms, will greatly aid in management efforts. In the mean time, the cautionary principle should remain in place to try to prevent the future releases of exotic bee species as well as special protection for environmentally sensitive areas. 


\section{REFERENCES}

Adams, D. (2007). The economics and law of invasive species management in Florida. Dissertation University of Florida. University of Florida Press.

Anderson, W.R. (1979). Floral conservatism in Neotropical Malpighiaceae. Biotropica 11(3): 219-223.

Ashman, T.L., Knight, T.M., Steets, J.A., Amarasekare, P., Burd, M., Campbell, D.R., Dudash, M.R., Johnston, M.O., Mazer, S.J., Mitchell, R.J., Morgan, M.T. \& Wilson, W.G. (2004). Pollen limitation of plant reproduction: Ecological and evolutionary causes and consequences. Ecology 85: 2408-2421.

Barthell, J. F., Randall, J. M., Thorp, R. W. \& Wenner, A. M. (2001). Promotion of seed set in yellow star-thistle by honey bees: Evidence of an invasive mutualism. Ecological Applications, 11(6): 1870-1883.

Beggs, J.R. \& Wilson, P.R. (1991). The Kaka Nestor meridionalis, a New Zealand parrot endangered by introduced wasps and mammals. Biological Conservation, 56: 23-38.

Booth, R.G., Cross, A.E., Fowler, S.V. \& Shaw, R.H. (1995). The biology and taxonomy of Hyperaspis pantheriina (Coleoptera: Coccinellidae) and the classical biological control of its prey Orthenzia insignis (Homoptera: Ortheziidae). Bulletin of Entomological Research, 85: 307-314.

Buchmann, S. L. (1987). The ecology of oil flowers and their bees. Annual Review of Ecology and Systematics, 18: 343-369.

Burd, M. (1994a). A probabilistic analysis of pollinator behavior and seed production in Lobelia deckenii. Ecology, 75(6): 1635-1646.

Burd, M. (1994b). Bateman's principle and plant reproduction: the role of pollen limitation in fruit and seed set. Botany Review 60: 83-139.

Butz Huryn, V. M. (1997). Ecological impacts of introduced honey bees. The Quarterly Review of Biology, 72(3): 275-297.

Butz Huryn, V.M. \& Moller, H. (1995). An assessment of the contribution of honey bees (Apis mellifera) to weed reproduction in New Zealand protected natural areas. $N Z J$ Ecology, 19:111-22.

Cox, P.A. (1983). Extiction of Hawaiin Avifauna resulted in change of pollinators in ieie, Freycentia arborea. Oikos, 41:195-99. 
D'Antonio, C. M. \& Vitousek, P. M. (1992). Biological invasions by exotic grasses, the grass/fire cycle, and global change. Annual Review of Ecology and Systematics, 23: 63-87.

Dafni, A. (1992). Pollination Ecology: a practical approach. Institute of Evolution Haifa University. Oxford University Press, New York.

Dafni A. \& Shmida, A. (1996). The possible ecological implications of the invasion of Bombus terrestris (L.) (Apidae) at Mt. Carmel, Isreal. In: Matheson AC, Buchmann SL, O'Toole C (eds) The Conservation of Bees. The Linnean Society of London and the International Bee Research Association, London, 183-200.

Donovan, B.J. (1990). Interactions between native and introduced bees in New Zealand. New Zealand Journal of Ecology, 3: 104-117.

Didham, R. K., Tylianakis, J. M., Gemmell, N. J., Rand, T. A. \& Ewers, R. M. (2007). Interactive effects of habitat modification and species invasion on native species decline. Trends in Ecology \& Evolution, 22(9): 489-496.

Ewel, J. J. \& Myers, R. L. (1990). Ecosystems of Florida. Orlando: University of Central Florida Press.

Frankie, G. W.,Vinson, S.B., Newstrom, E. \& Barthell, J.F. (1988). Nest site and habitat preferences of Centris bees in the Costa Rican Dry Forest. Biotropica, 20: 301-310.

Goka, K., Kimiko O. \& Masahiro Y. (2006). Worldwide migration of parasitic mites as a result of bumblebee commercialization: special feature: population ecology of biological invasion. Population Ecology, 48(4): 285-291.

Goldschmidt, T. (1996). Darwins Dream Pond: Drama in Lake Victoria. Cambridge, Massachusetts: Massachusetts Institute of Technology Press.

Gordon, D. R. (1998). Effects of invasive, non-indigenous plant species on ecosystem processes: lessons from Florida. Ecological Applications, 8(4): 975-989.

Goulson, D. (2003). Effects of introduced bees on native ecosystems. Annual Review of Ecology, Evolution, and Systematics, 34: 1-26.

Groom, (1998). Allee effects limit population of an annual plant. American Nat. 151: 487-496.

Groombridge, B (1992). Global Biodiversity: Status of Earth's living resources. London, UK: Chapman Hall. 
Gross C.L. \& Mackay D. (1998). Honeybees reduce fitness of pioneer shrub Melastoma affine (Melastomataceae). Biological Conservation, 86: 169-178.

Hingston, A. B. \& McQuillan, P.B. (1999). Displacement of tasmanian native megachilid bees by the recently introduced bumblebee Bombus Terrestris (Hymenoptera : Apidae). Australian Journal of Zoology, 47(1): 59.

Kearns, C. A., Inouye, D. W. \& Waser, N. M. (1998). Endangered mutualisms: the conservation of plant-pollinator interactions. Annual Review of Ecology and Systematics, 29: 83-112.

Knight T.M., Steets, J.A., Vamosi, J.C., Mazer, S.J., Burd, M., Campbell, D.R., Dudash, M.R., Johnston, J.O., Mitchell, R.J. \& Ashman, T.L. (2005). Pollen limitation of plant reproduction: pattern and process. Ecology, 36: 467-497.

Koptur, S. (2006). The Conservation of specialized and generalized pollination systems in subtropical ecosysytems: a case study, In Ch. 15 in Ollerton, J. \& Waser, N. M. (2006). Plant-pollinator interactions: from specialization to generalization. Chicago: University of Chicago Press.

Lacey, J.R., Marlow, C.B. \& Lane, J.R. (1989). Influence of spotted knapweed (Centaurea maculosa) on surface runoff and sediment yield. Weed Technology (4) 3: 627-632.

Larson, B.M.H. \& Barret S.C.H. (2000). A comparitve analyses of pollen limitation in flowering plants. Biology Linnean Society, 69: 503-520.

Liu, H. \& Pemberton, R. W. (2009). Solitary invasive orchid bee outperforms cooccurring native bees to promote fruit set of an invasive Solanum. Oecologia, 159, $515-525$.

Liu, H., Pemberton, R. W. \& Stiling, P. (2006). Native and introduced pollinators promote a self-incompatible invasive woody vine (Paederia foetida) in Florida. Journal of the Torrey Botanical Society, 133(2): 304-311.

Liu, H., Stiling, P. \& Pemberton, R. W. (2007). Does enemy release matter for invasive plants? evidence from a comparison of insect herbivore damage among invasive, noninvasive and native congeners. Biological Invasions, 9(7): 773-781.

Lodge, T. E. \& Ebrary, I. (2005). The Everglades Handbook: Understanding the ecosystem (2nd ed.). Boca Raton, Fla.: CRC Press.

Mack, R. N., Simberloff, D., Lonsdale, W. M., Evans, H., Clout, M. \& Bazzaz, F. A. (2000). Biotic invasions: Causes, epidemiology, global consequences, and control. Ecological Applications, 10(3): 689-710. 
Melián, C. J. (2006). Review: Plant-pollinator interactions: What are they telling us about community assembly, conservation, and ecosystem management? Plant-pollinator interactions: From specialization to generalization. Ecology, 87(10): 2683-2685.

Myers, R.L. \& J.J Ewel (1990). Ecosystems of Florida. The University of Central Florida Press, Gainsville, Florida, 230-271.

Michener, C.D. (2000). The Bees of the World. Johns Hopkins University Press, Baltimore, Maryland.

Nadel, H., Frank, H. \& Knight, R.J. (1992). Escapees and accomplishes: the naturalization of exotic Ficus and their associated faunas in Florida. Florida Entomology, 75:29-39.

O’Dowd, D.J., Green, P.T. \& Lake, P.S. (2003). Invasional 'meltdown' on a oceanic island. Ecology Letters, 6: 812-817.

Olmstead, A. L. \& Wooten, D. B. (1987). Bee pollination and productivity growth: the case of alfalfa. American Journal of Agricultural Economics, 69(1): 56-63.

Olson, D. M. \& Dinerstein, E. (2002). The global 200: priority ecoregions for global conservation. Annals of the Missouri Botanical Garden, 89(2): 199-224.

Ortega, Y. K. \& Pearson, D. E. (2005). Weak vs. strong invaders of natural plant communities: assessing invasibility and impact. Ecological Applications, 15(2): 651661 .

Paini, D. \& Roberts J. D. (2005). Commercial honey bees reduce the fecundity of an Australian native bee. Biological Conservation, 123(1): 103-112.

Pascarella, J. B., Waddington, K.D. \& P. R. Neal. (1999). The bee fauna (Hymenoptera: Apoidea) of Everglades National Park. Florida and adjacent areas: distribution, phenology, and biogeography. Journal Kansas Entomol. Soc., 72: 32-45.

Paton, D.C. (1990). Budgets for the use of floral resources in malee heath. In The Malee Lands: A conservation Perspective, ed JC Noble, PJ Joss, GK Jones, Melbourne CSIRO: 189-93.

Pejchar, L. \& Mooney, H. A. (2009). Invasive species, ecosystem services and human well-being. Trends in Ecology \& Evolution, 24(9): 497-504.

Pemberton, R. W. \& Liu, H. (2008a). Potential of invasive and native solitary specialist bee pollinators to help restore the rare cowhorn orchid (Cyrtopodium punctatum) in Florida. Biological Conservation, 141(7): 1758-1764 
Pemberton, R. W. \& Liu, H. (2008b). Naturalization of the oil collecting bee Centris nitida (Hymenoptera, Apidae, Centrini), a potential pollinator of selected native, ornamental, and invasive plants in Florida. Florida Entomologist, 91(1), 101-109.

Pemberton, R. W. \& Liu, H. (2008c). Naturalized orchid bee pollinates resin-reward flowers in Florida: Novel and known mutualisms. Biotropica, 40(6): 714-718.

Pemberton, R. W. \& Liu, H. (2009). Marketing time predicts naturalization of horticultural plants. Ecology, 90(1): 69-80.

Pimentel, D., Lach, L., Zuniga, R. \& Morrison, D. (2000). Environmental and economic costs of nonindigenous species in the United States. Bioscience, 50(1): 53-65.

Ramsey, M. W. (1988). Differences in pollinator effectiveness of birds and insects visiting Banksia menziesii (Proteaceae). Oecologia, 76(1): 119.

Rhymer, J. M. \& Simberloff, D. (1996). Extinction by hybridization and introgression. Annual Review of Ecology and Systematics, 27: 83-109.

Richardson, D. M. (2000). Plant invasions-the role of mutualisms. Biological Reviews of the Cambridge Philosophical Society, 75(1): 65-93.

Richardson, D. M., Pysek, P., Rejmanek, M., Barbour, M. G., Panetta, F. D. \& West, C. J. (2000). Naturalization and invasion of alien plants: Concepts and definitions. Diversity and Distributions, 6(2): 93-107.

Roubik, D. W. (1989). Ecology and natural history of tropical bees. Cambridge ; New York: Cambridge University Press.

Roubik, D. W. (2002). The value of bees to the coffee harvest. Nature, 417: 708.

Roubik, D. W. \& Hanson P.E. (2004). Abejas de orquídeas de la américa tropical: Biología y guía de campo. Orchid bees of tropical america: Biology and field guide. San José, Costa Rica: Editorial.

Savidge, J. A. (1987). Extinction of an island forest avifauna by an introduced snake. Ecology, 68(3): 660-668.

Schmitz, D.C, Simberloff, D, Hofstetter, H., Haller, W. \& Sutton, D. (1997). The ecological impact of non-indigenous plants. Strangers in Paradise, 39-61; Washington D.C: Island Press. 
Shelly, R.L, Jacobs, J.S. \& Carpinelli, M. F. (1998). Distribution, Biology, and Management of diffuse knapweed (Centaurea diffusa) and spotted knapweed (Centaurea maculosa). Weed Technology, 12: 353-362.

Sigrist, M.R. \& Sazima, M. (2004). Pollination and reproductive biology of twelve species of neotropical Malpighiaceae: Stigma morphology and its implications for the breeding system. Annals of Botany, 94 (1): 33-41.

Snelling, R. R. (1984). Studies on the taxonomy and distribution of American Centridine bees (Hymenoptera: Anthophoridae). Contributions in Science (Los Angeles), 347: 169.

Stout J.C., Kells, A.R. \& Goulson, D. (2002). Pollination of the invasive exotic shrub Lupinus arboreus (Fabaceae) by introduced bees in Tasmania. Biological Conservation, 106: 425-434.

Thompson, J. D. (1991). The biology of an invasive plant. (Spartina anglica).Bioscience, 41: 393-401.

Vitousek, P. M. \& Walker, L. R. (1989). Biological invasion by Myrica faya in Hawai'i: Plant demography, nitrogen fixation, ecosystem effects. Ecological Monographs, 59(3): 247-265.

Whitfield, P.E, Gardner, T., Vives, S.P., Gilligan, M. R., Courtenay Jr., W.R., Ray, G. \& Hare, J.A. (2002).Biological invasion of the Indo-Pacific lionfish Pterois volitans along the Atlantic coast of North America. Marine Ecology Progress Series. 235: 289-297. 


\section{APPENDICES}

Appendix 1. Post Hoc pairwise comparisons; Tukey HSD

Dependent Variable: Fruit set

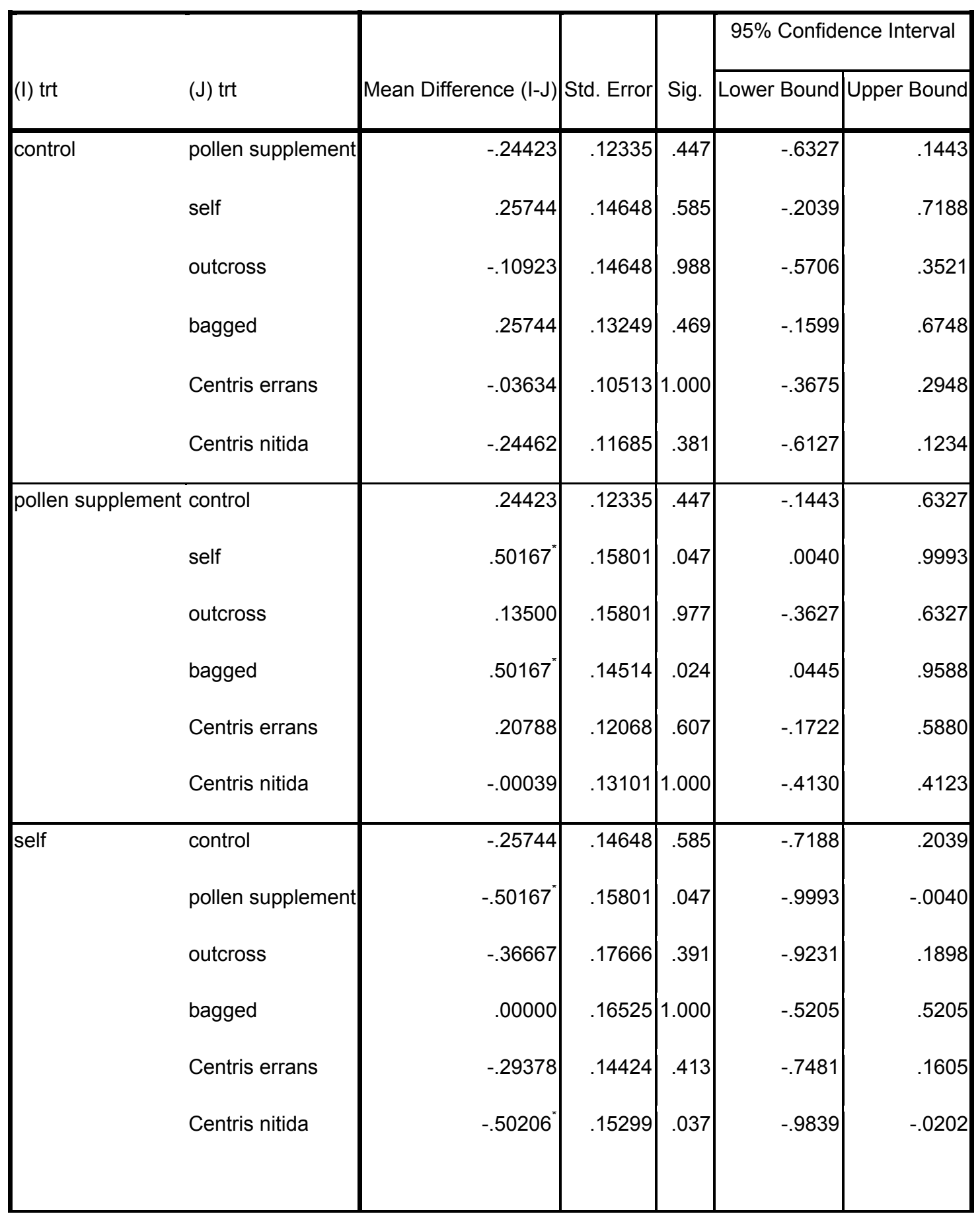




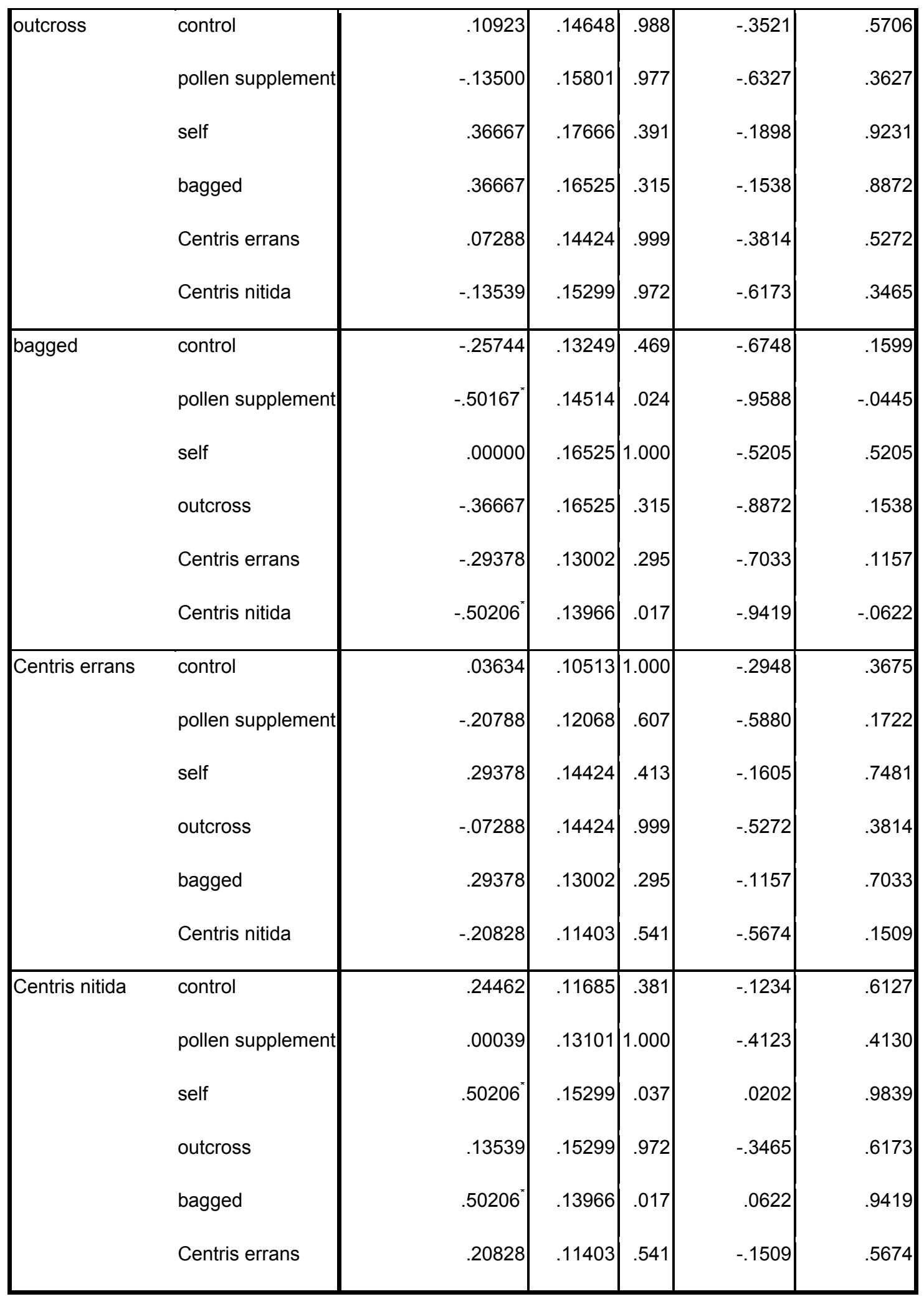

*. The mean difference is significant at the 0.05 level. 
Appendix 2. One-Way ANOVA table indicating significantly higher fruit set in outcross pollination treatments vs. self pollination treatments in Byrsonima lucida.

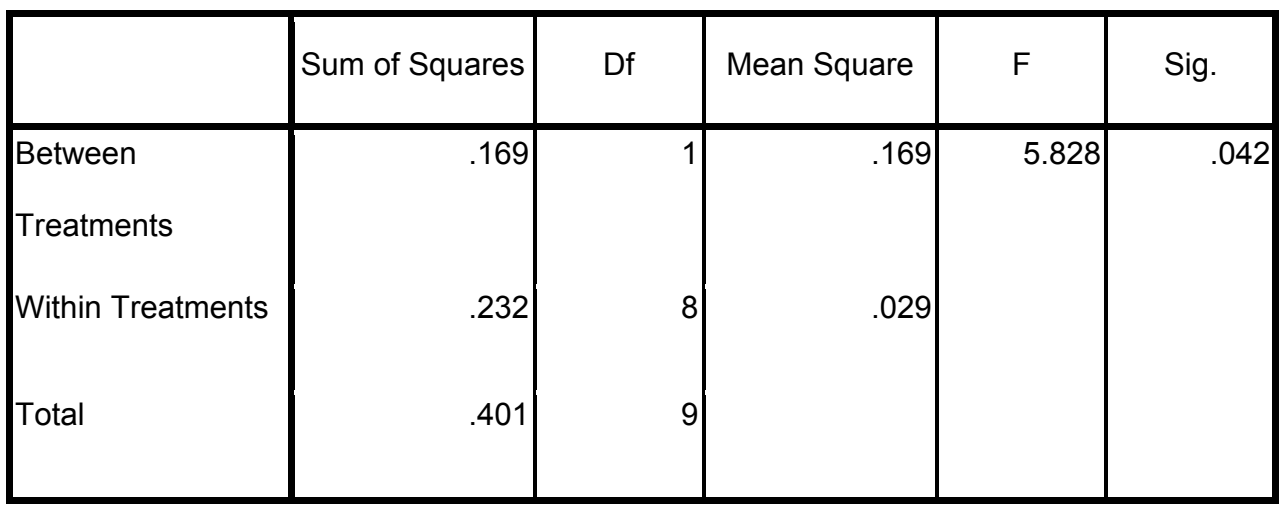

Appendix 3. Post Hoc Pair-wise comparison of mean visitation rates among different floral visitors using; Tukey HSD.

\section{Multiple Comparisons}

Dependent Variable: Visitation rate

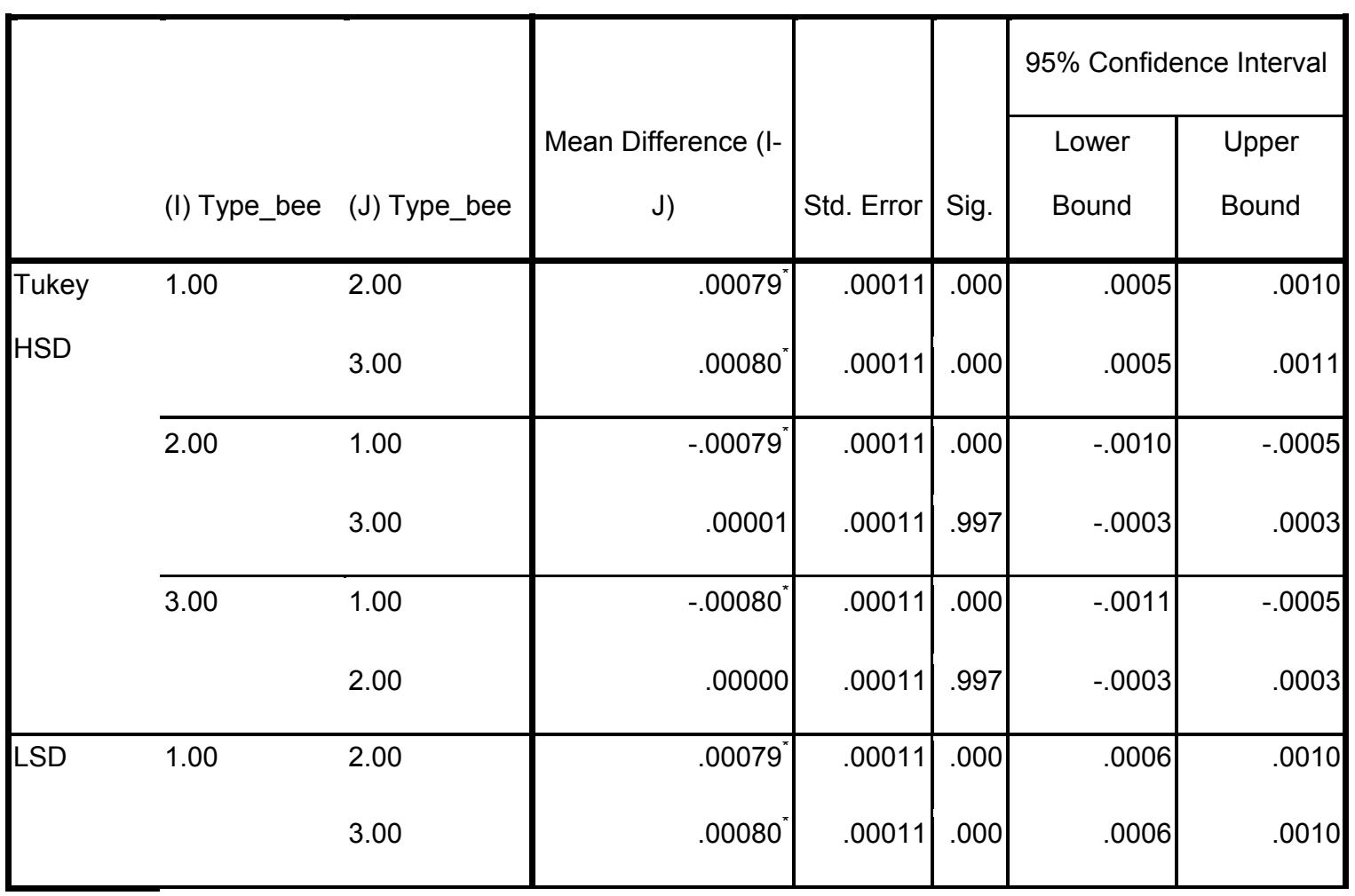




\begin{tabular}{|rr|r|r|r|r|r|}
\hline 2.00 & 1.00 & -.00079 & .00011 & .000 & -.0010 & -.0006 \\
& 3.00 & .00001 & .00011 & .945 & -.0002 & .0002 \\
\hline 3.00 & 1.00 & $-.00080^{\circ}$ & .00011 & .000 & -.0010 & -.0006 \\
& 2.00 & .00000 & .00011 & .945 & -.0002 & .0002 \\
\hline
\end{tabular}

*. The mean difference is significant at the 0.05 level. 